\title{
Power and satire in the front-page images of Mariano Rajoy: visual motifs as political humour
}

\author{
Manuel Garin \\ Universitat Pompeu Fabra, Spain \\ manuel.garin@upf.edu
}

\section{Daniel Pérez-Pamies}

Universitat de Girona, Spain

daniel.perez@udg.edu

\begin{abstract}
This article explores the use of photography and visual motifs as forms of political humour in contemporary media. By studying the representation of former Prime Minister of Spain Mariano Rajoy in the front pages of three Spanish newspapers (El Mundo, El Pais and La Vanguardia) between 2011 and 2017, the paper identifies and questions the liaisons between power and satire present in the so-called "serious" press, focusing on how different photographic traits concerning layout, composition and gestures reflect ideological choices. This photographic satire developed by printed media is then framed within a figurative tradition that goes back to Spanish royal portraiture, from Velázquez to Goya, which employs common strategies for the visual depiction of power, including satirical and humorous attributes to push specific political agendas. This examination, based on the quantified study and the visual analysis of more than 7,500 front pages, is part of the national research project Visual Motifs in the Public Sphere: Production and Circulation of Images of Power in Spain, 2011-2017. In order to determine a useful procedural approach to satirical expressions in photographs, defining which front pages invoke a remarkable satirical content, this article also presents a comparative study and a categorisation based on formal (im)balances related to the concepts of visual motif and humour.
\end{abstract}

Keywords: front page, photography, power, satire, visual motifs

\section{Introduction}

In the current context of extreme mediatisation of the political sphere (Agamben 2000), when the production and circulation of images permeates every aspect of public life, it has become increasingly common to find satirical photographs in places and spaces that not so long ago were restricted to serious (or at least not deliberately humorous) images. While visual satire has enjoyed a stable presence in news coverage for centuries, in the form of political cartoons, 
caricatures or parliamentary sketches, the humour of such images tended to be contained within the limits of a specific section inside the newspaper, reinforcing the sense of "proper place" or "proper genre" that helped audiences distinguish between information and opinion, objectivity and subjectivity, seriousness and humour. As questionable as all those binaries may be, the very structure of newspapers and the classical ethos of journalism used to reinforce the distinction between images that could appear in the front page and images that could not, photographs that remained within informational boundaries and photographs that did not, with humour being a key variable to distinguish (and police) the suitability of images for news coverage. But, in recent years, falling within a pattern of intense aesthetisation of the public sphere (Rancière 2004; Ngai 2012) and of intense (self)satirisation of political practices (Holm 2017), it has become commonplace to find overtly humorous photographs in the front pages of respected newspapers, that is, in the very same place where satirical images rarely appeared a few decades ago.

The goal of this article is to analyse that shift in the modes and spaces of photographic satire within the so-called "serious press" or "reference press" (González et al. 2010), focusing on a case study of more than 7,500 front pages from the three main Spanish newspapers (El País, El Mundo and La Vanguardia) published between 2011 and 2017. The size and scope of this database is related to the research project Visual Motifs in the Public Sphere: Production and Circulation of Images of Power in Spain, 2011-2017, the aim of which is to assemble a critical archive of photographs, videos and other visual materials that exemplify how public institutions and media conglomerates produce, select and disseminate images of power, by quantifying and analysing them within different spheres of representation: political, civil, economical, judicial, military/armed, religious and monarchic. Centred on the political sphere, this article tackles a specific group of images within the project, that is, the numerous satirical depictions of the former Prime Minister Mariano Rajoy, from his rise to power until his impeachment.

\section{Methodology, data and research questions}

The article's methodology combines four key approaches to the study of images and visual language: iconological critique and photographic analysis (Berger, 1972; Sontag, 1977), social semiotics (Kress \& van Leeuwen 1998), visual motifs (Balló \& Bergala 2016) and production studies (Banks \& Mayer 2009, 2015). First, we have focused not only on the formal patterns of each photograph but also on its links with art history from a critical standpoint, acknowledging the power mechanisms and social inequalities behind the frame, tied to the different spaces and public events where Rajoy was depicted. Secondly, social semiotics has been useful to avoid an "essentialist" approach to the corpus of images, that is, to relate the strictly visual variables of each photograph with other key aspects such as written language, graphic layout and editorial conditions. Thirdly, the study of visual motifs lies in the core of the article's methodology, given that in order to group and analyse all the front page photographs, we have focused on elements of repetition and difference between them, in order to find when, why and how an isolated image becomes a recurrent motif with its own themes and variations (see section 3 ). And finally, we have applied production studies contacting the different photographers that took Rajoy's pictures to learn a bit more about how the images were conceived and edited from the perspective of photojournalism.

Among the 498 images of Rajoy published on the covers of El País, El Mundo and La Vanguardia between 2011 and 2017, during the harshest years of a profound economical and territorial crisis in Spain, up to 150 photographs arguably portray gestures, poses or grimaces of the Prime Minister in humorous ways. Such a strikingly high figure, around $30 \%$ of all Rajoy front-page images from the three most read newspapers, raises fundamental questions about the 
choices made by the photographers, layout artists and editors responsible for their publication; an entire production chain that internalised and coded his public image as humorous. While our analysis of the sample is mostly qualitative and its categorisation relies on visual markers of humorousness (movements, gestures, facial expressions), we believe that our research points to symptomatic issues concerning humour and politics, summarised in three main research questions. First, which economic, political and social interests drive the newspaper's choice of a humorous or satirical image? That is, how does the Fourth Estate exert power visually? Secondly, to what extent is the politician's behaviour self-conscious and thus capable of influencing the camera's depiction of his own facial expressions and gestures? And, finally, how can readers cope with and respond to those representational strategies in our image driven society, where humour increasingly operates as a mediator of political agency?

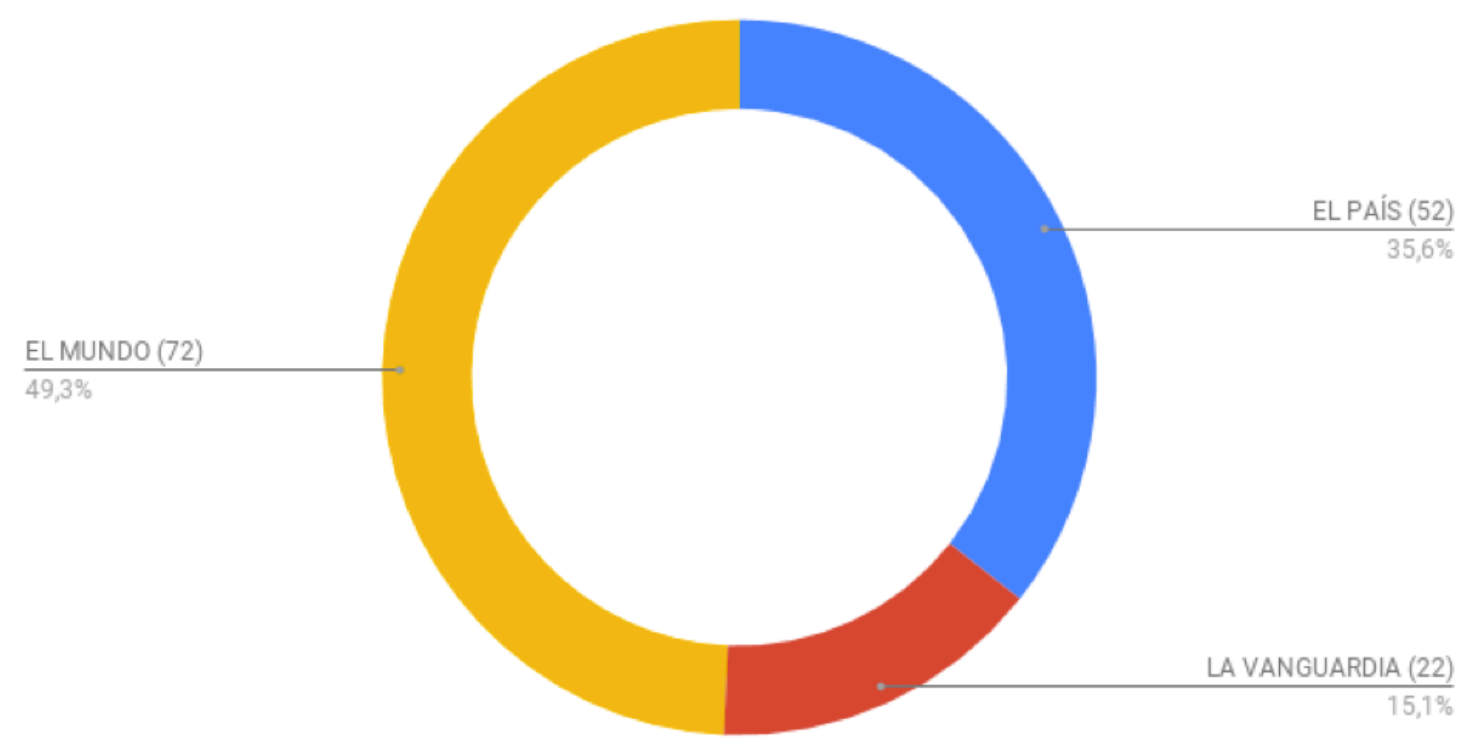

Fig. 1. Distribution of satirical images between the three newspapers, 2011-2017

In that sense, one of the most surprising findings of our research is that the satirical front-page images of Rajoy are more prevalent in the neocon and right-wing El Mundo than in the more progressive and centre-left El País (see percentages in Figure 1), meaning that he was mocked more frequently and directly by the newspaper supposed to be "on his side" than by his alleged political opponents. This brings to mind Nicholas Holm's (2017: 25) critique of the misconception of satire as something supposed to be intrinsically liberal and progressive. When comparing the three newspapers (for readers not familiar with Spanish media), El Mundo is arguably the one with a more right wing and neoliberal agenda, closer to the politics of Rajoy's party, PP, whereas El Pais has traditionally supported the views of PSOE, on the mainstream centre-left, and the Barcelona-based La Vanguardia (founded a century earlier than the other two) defends a conservative business-oriented agenda aligned with the Catalan bourgeoisie. Therefore, the fact that El Mundo satirised Rajoy more consistently and more fiercely than $E l$ Pais, points to the complex, volatile and opaque links between the political sphere and the media, as we will later see by focusing on the satirical attacks of its founder and former chief editor, Pedro J. Ramírez. Where are the boundaries between information and opinion, neutrality and satire, the kind of image that should be published in a front page and the kind that shouldn't?

While the perception of leaders is nationally specific and depends on the way they handle situations (Sola \& Hernández 2013), anyone familiar with the Spanish media context would acknowledge that the use of humorous photographs of Rajoy contributed to his political demise 
in complex and often contradictory ways, which blend with the general atmosphere of distrust, mockery and cynicism towards politicians that seems to be growing in different Western democracies (Polo \& Cardenas 2014; Berlant \& Ngai 2017). So we believe that this analysis of Spanish front pages is consistent with recent studies of power and satire from a transnational perspective (Meijer Drees \& De Leeuw 2015), and can shed light on similar practices taking place in the press of other European countries, such as the blatantly satirical photographs of Theresa May and Boris Johnson selected for the coverage of Brexit in "respected" newspapers such as The Guardian. Hopefully, the article will connect with previous research on the interplay of power, humour and dignity (Kuipers, 2015), a phenomenon that increasingly blurs the boundaries between the public image of comedians and politicians, shifting from the age of Coluche or Grillo to the age of Trump, Kim Jong-un and Salvini.

\section{Mocking photographs: front page images as satirical motifs}

In her seminal work on the relations between photography and power in capitalist societies, Susan Sontag (1977: 178) already identified the key issue when analysing photographs in mass media:

Cameras define reality in the two ways essential to the workings of an advanced industrial society: as a spectacle (for masses) and as an object of surveillance (for rulers). The production of images also furnishes a ruling ideology. Social change is replaced by a change in images.

This is perhaps the most challenging and dangerous aspect of what images mean and do in contemporary societies, not so much because of the uses politicians or institutions may give to them (power has always manufactured images, from cathedrals to royal portraiture), but because, in spite of the monumental proliferation of visual inputs that surround everything today, the tools and abilities to interpret them, to make sense of the "change in images" Sontag referred to, are scarce and insufficient. Visual hegemony in contemporary societies has not been accompanied by visual literacy, and as Kress \& van Leeuwen (2006: 114) pointed out years ago, the extremely complex and ideological production process of most images (from the photographer who took the shot to the chain of graphic designers, layout artists and editors) remains hidden to the general public.

Therefore, we think it is crucial to the health of mediated democracies to unveil the visual strategies used for the production of humorous images representing power. Because it is only by identifying and historicising the mechanisms behind a photograph that we might be able to understand (and cope with) the mixture of surveillance and spectacle it hides, the tension between the rulers and the ruled. During the sampling and cataloguing of our front-page database, we were frankly surprised by the sheer volume of images that openly engaged in comical or satirical depictions of Rajoy in "serious" newspapers. All these images were not in an inside section of the paper but on its very front page, an unavoidable and consequential visual statement that manifests the relationship between governmental power and media power. So instead of analysing retouched or photo-shopped images that are deliberately satirical, we focus on allegedly neutral photographs the humour of which is conveyed in subtler but still prevalent ways. These are journalistic photos that according to Roland Barthes (1981: 38) are not supposed to "speak too much" but remain deeply coded.

Since the satirical depiction of Rajoy was methodical and repetitive, this section of the article seeks to familiarise our readers with the most recurrent images, grouping them according to the particular choices made by photographers, designers and journalists, before getting deep into the iconographical, historical and critical analysis in section 4. As Kaplan (2017: 14) proves in his recent monograph on photography and humour, in spite of the apparently neutral aspect 
of photographs (the fact that they seem real), photographers, artists and editors have been well aware of the comical possibilities of the medium since its origins:

through the satirical use of visual stereotypes, the camera has served as the technological agency for many types of laughter [...] realistic and unrehearsed photographs are capable of generating comedy. As such, it becomes the goal of the sensitive photographic eye to be on the lookout for such comic situations in the documentation of everyday life.

So, first of all, what are the visual stereotypes and patterns used by the "photographic eye" of the Spanish press for the satirical depiction of Rajoy?
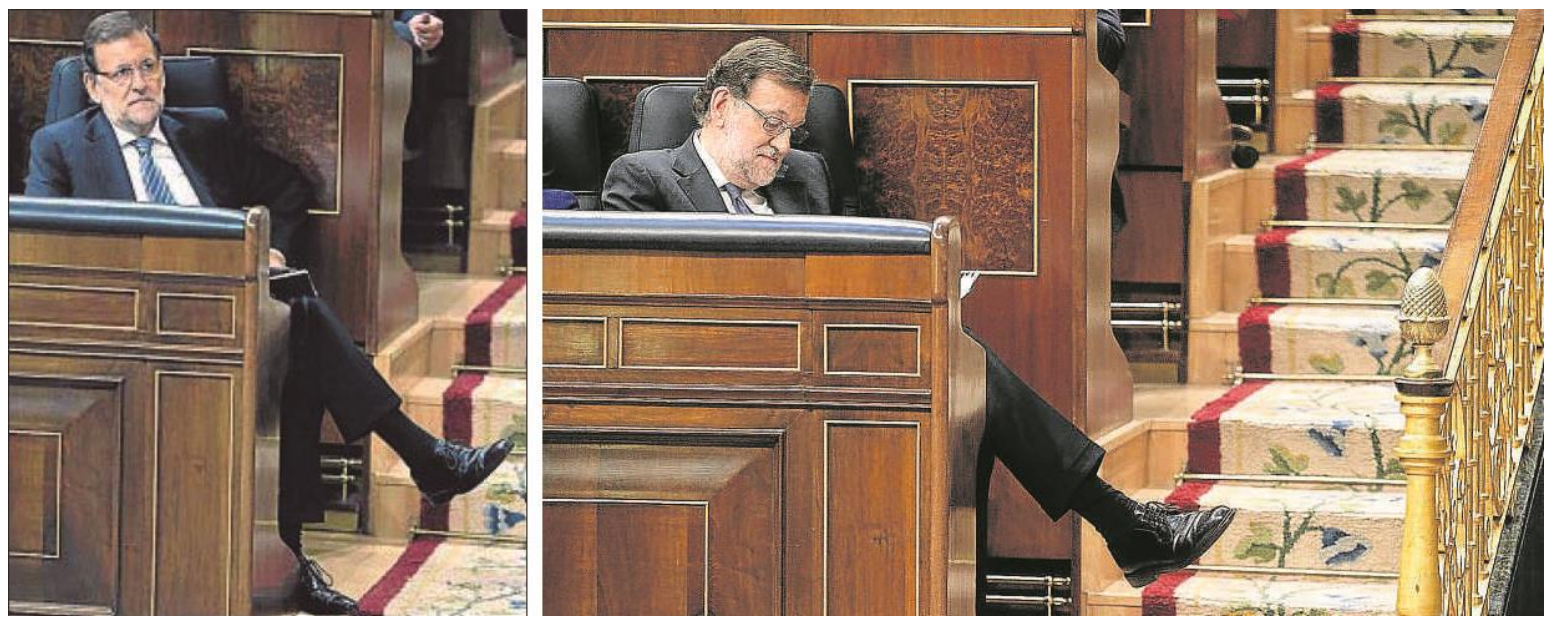

Fig. 2. La Vanguardia, November $28^{\text {th }} 2014 \&$ April $7^{\text {th }} 2016$ (Emilia Gutiérrez)

In order to establish which images are humorous and which are not, we have assessed the gestural and compositional variables of every front-page photograph depicting Rajoy, looking for common and repetitive situations, gestures or facial expressions. Many front pages combine such visual forms with the written humour of headlines or captions (as we will later see), but while acknowledging that newspapers often combine the visual and the verbal for humorous purposes, we have chosen to focus on pictorial and compositional aspects instead of written words. In doing so, we have identified different groups of images that correspond to what Balló \& Bergala (2016) call visual motifs. These motifs are patterns of iconic representation that are (sub)consciously transmitted between painters, photographers and image makers as "ways of depicting" that generate "ways of seeing" according to specific formal patterns. From the positions of characters within the frame - such as La Pietà in representations of suffering - to gestures, movements, distances, camera angles, lightening palettes or editing and montage. As the two images in Figure 2 show, such representational choices become visual motifs when different images deploy the same iconographical strategies in different moments, here emphasising Rajoy's informal posture (his legs) during parliamentary sessions. Consequently, we have grouped the sample in a series of recurrent, identifiable motifs that prove how many photojournalists and editors were coding the Prime Minister's image as humorous, visually. 


\subsection{Props, costumes, gimmicks}
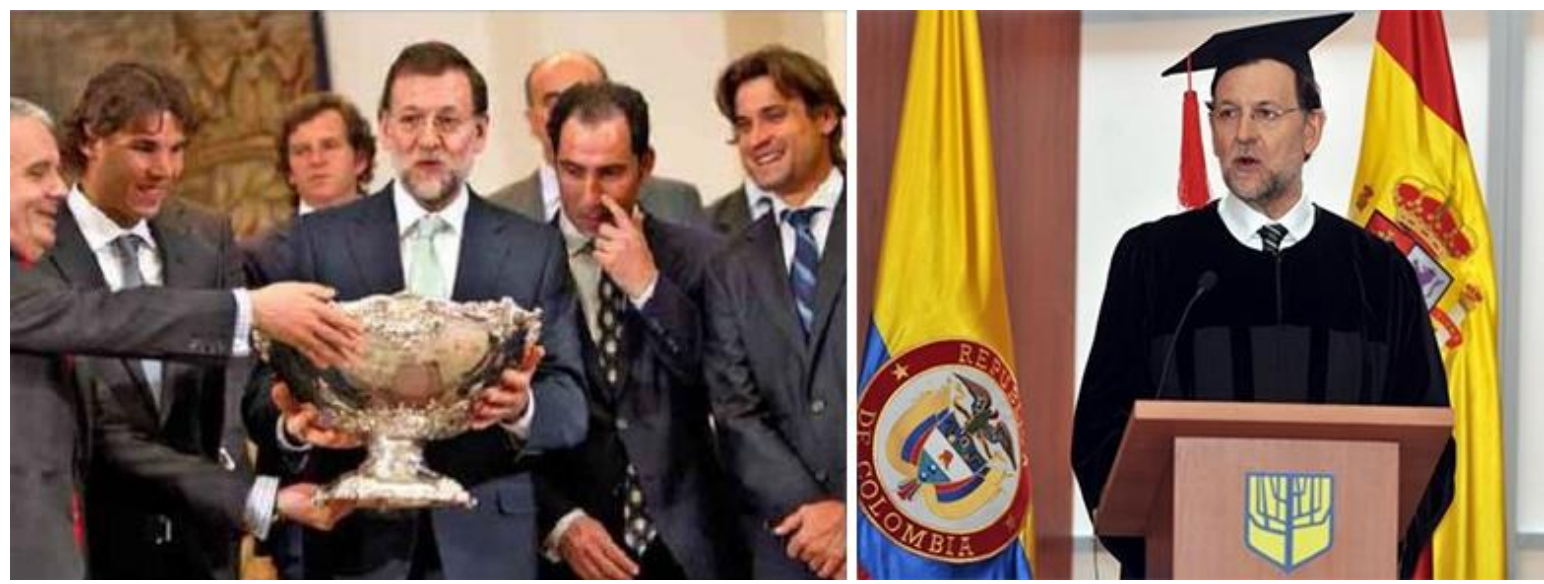

Fig. 3. El Mundo February $15^{\text {th }}$ (Alberto di Lolli) and April $20^{\text {th }} 2012$ (Guillermo Legaria)

The first kind of visual motif satirises Rajoy as unable to handle objects in the proper way and dressed in a variety of costumes and professional attires that create a clownish effect, as seen in the two El Mundo front pages in Figure 3: the first one depicts him with the Davis Cup "salad bowl" trophy and is similar to other humorous photos where he mishandles helmets, microphones and clocks; the second one was taken in Colombia when he was invested doctor honoris causa and, according to the photographer himself, it captures a chistoso moment (reminiscent of the Nutty Professor). Such images bring to mind what Carroll (1991) calls mimed metaphors and objects analogues when referring to the humorous interactions between objects and bodies in slapstick comedy (Garin 2014: 168), as well as Berger's (2013: 38) analysis of the cultural, social and class signifiers present in photographs of suits: "Their suits deform them. Wearing them, they look as though they were physically misshapen [...]. None of their abnormalities is extreme. They do not provoke pity. They are just sufficient to undermine physical dignity." 


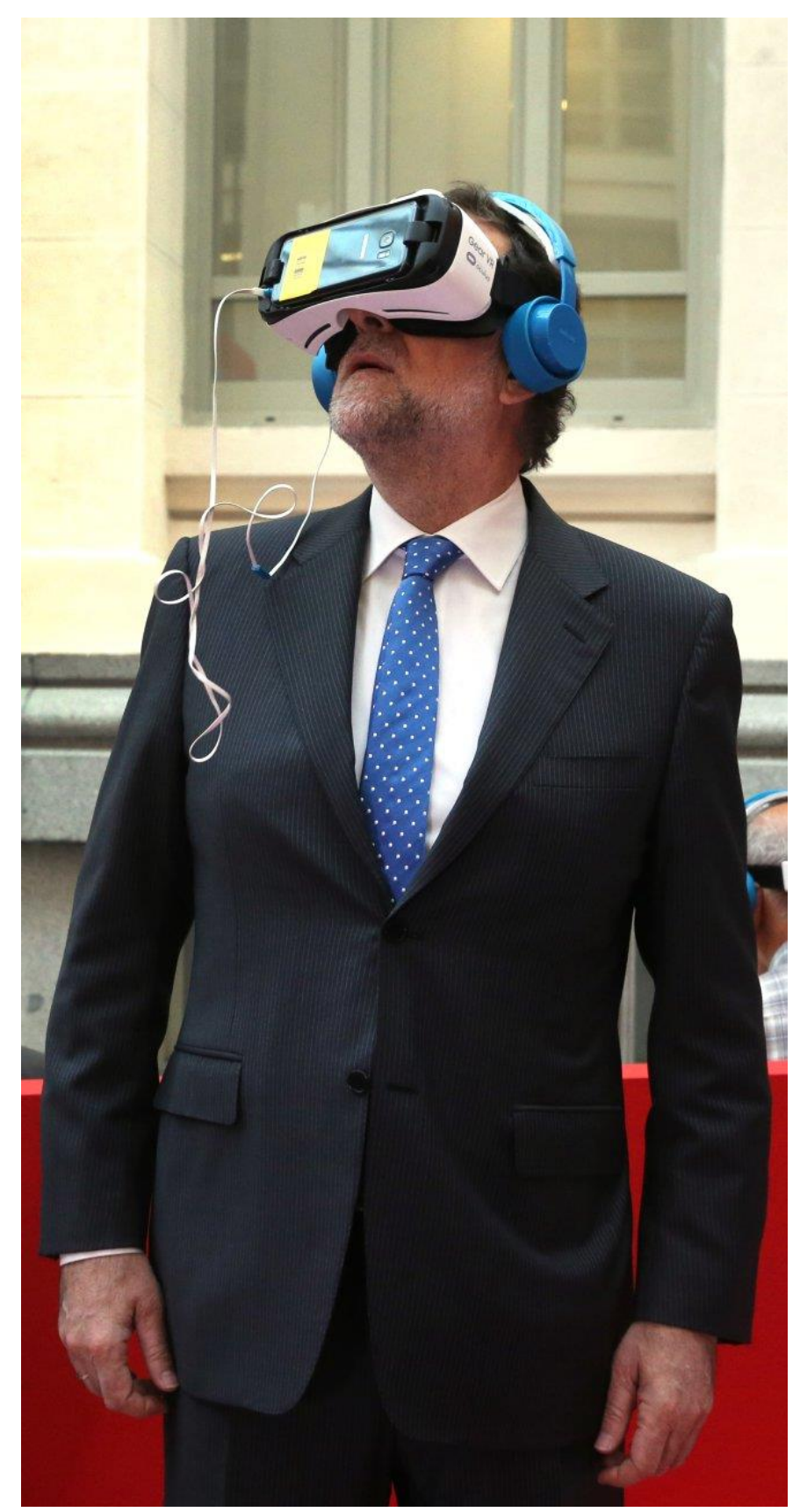

Fig. 4. El País May 5 2016 (Uly Martín)

A photograph that summarises Rajoy's backward relation with objects and costumes is the 2016 El País front page subtitled "Rajoy discovers virtual reality," taken during a party organised by the newspaper for its $40^{\text {th }}$ anniversary (Figure 4). The contrast between the state-of-the-art technology of the object (a VR headset) and his strange posture (head cocked to one side and mouth slightly agape) makes him look clueless, apparently unfit for the technological challenges of a $21^{\text {st }}$ century government. Published in May $5^{\text {th }} 2016$, once Rajoy's comic persona had already been established in hundreds of front pages (as we will later see) the photograph is not an incidental joke but a harsh satirisation of his inability to cope with the challenges of contemporary politics, unable to "see" what's going on around him (corruption scandals, the economical and territorial crisis, his own impeachment) to the extent of needing some sort of technological device to figure out what's real and what's not. This absurd clash between the tooold and the too-new, between Rajoy's posture and the VR goggles, connects with Ngai's (2017: 
475) analysis of the gimmick as a central motif to understand the liaisons of humour, aesthetics and late capitalism.

Tellingly, the most archaic comparison that Rajoy endured during his presidency was being compared with an estafermo or quintain, a medieval mannequin/sandbag set up as a mark in tilting with a lance (see also section 4.2). The Prime Minister was made to embody the Bergsonian theory on the mechanics of visual comedy (Bergson 1911) as amplified by historian Gunning (1995), two references that inform Ngai's (2017) thoughts on the gimmick. But unlike other politicians such as Vladimir Putin, who seems to be in full command of objects and costumes in his frequent hypermasculine photographs (as soldier, bike raider, hunter, scuba diver, pilot, spy, and so on), Rajoy's interaction with props and gadgets is visually framed as a clash between the medieval and the contemporary, the quintain and the gimmick. Instead of commanding or assertive, his relation with objects seems humorous and contingent, reflecting Rob King's point about the difference between tool-based humour (based on laughable ineptitude and rough physics: the Stooges) and machine-based humour (more stylised and procedural: Keaton), with Rajoy embodying the former (King 2017: 174).

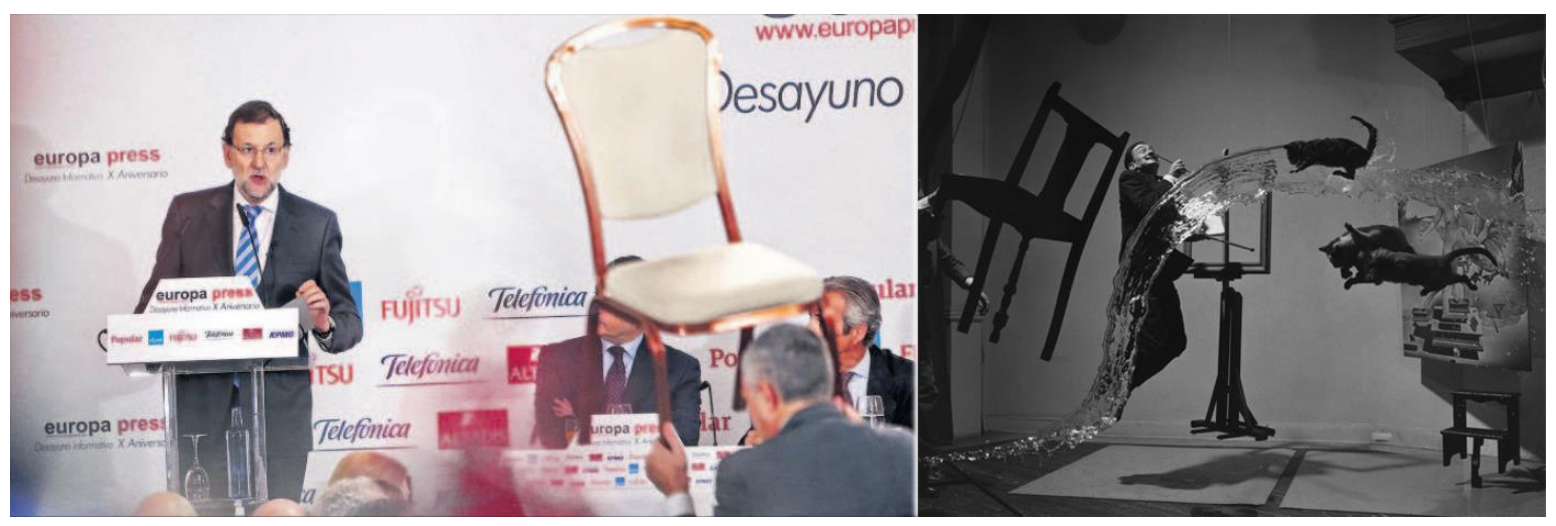

Fig. 5. El País, April 28 2015 (Samuel Sánchez) / Dali Atomicus (Philippe Halsman)

For further proof of how photographers and editors $d o$ choose specific photographs with satirical framings and compositions, notice how the depiction of Rajoy in Figure 5 evokes the tradition of interruptus comedy dating back to commedia dell'arte, and perpetuated in vaudeville or the Marx Brothers (where different objects interrupt the scene at will). More importantly, it links the satirisation of politicians with the surrealist avant-garde kind of photographic humour deployed in Philippe Halsman's famous portrait of Dalí with a flying chair: "Here, the viewer witnesses photography's uncanny ability to achieve suspended animation for humorous effect [...]. With space clearly out of joint, one sees the hand and body of the assistant, who holds up the chair on the left" (Kaplan 2017: 151). In Rajoy's case, the suspended chair is echoed by his suspended glance and gesture, all of which reflect his suspended tenure (in the sense of both suspense and suspension) as Spain's commander in chief. But instead of conveying a playful kind of object-based humour, as in Dalí's photo, the editors of El País embraced a harsher mode of visual satire suggesting that not even chairs respected Rajoy or that he clanged to his presidential chair.

\subsection{Backward gestures}

Few actions are as important for the representation of power as hand gestures (of command, appeasement or indifference) and, as Chaplin demonstrated in The Great Dictator (1945), those very same actions are a goldmine for political satire. According to the photographers we have interviewed, Rajoy's nervous and disjointed gestuality made it easier to capture a variety of 
strange or funny moments, such as a hilarious movement with parallel hands in front of King Juan Carlos, used by El Mundo in its October $13^{\text {th }} 2012$ front page, that for Spanish readers may evoke the physical comedy of Chiquito de la Calzada. Instead of selecting more dignified images to minimise Rajoy's self-undermining, the press preferred to stress and magnify his comicality. Such photographs frame the Prime Minister very closely, a strategy that, according to Kress \& van Leeuwen (2006: 126), signifies a lack of respect for authorities of various kinds: decorum is conveyed in open and respectful shots that "keep their distances" whereas much closer and caricaturesque framings deliberately break protocol. With the distance of the frame cuing a satirical context, it's only a matter of choosing some authoritative motifs to mock, such as the traditional gesture of command (pointing towards something), emptied of all political dignity in the November $26^{\text {th }} 2015$ front page of El Pais when Rajoy appears as a football radio commentator narrating a Champions League match. As seen in two more examples (Figure 6), the connection of thumb and finger no longer transmits an OK message when combined with a bedazzled stare into one's own hand (governing a country is like looking for a needle in a haystack); and a thumb upward seems like hitchhiking or looking for a way out.
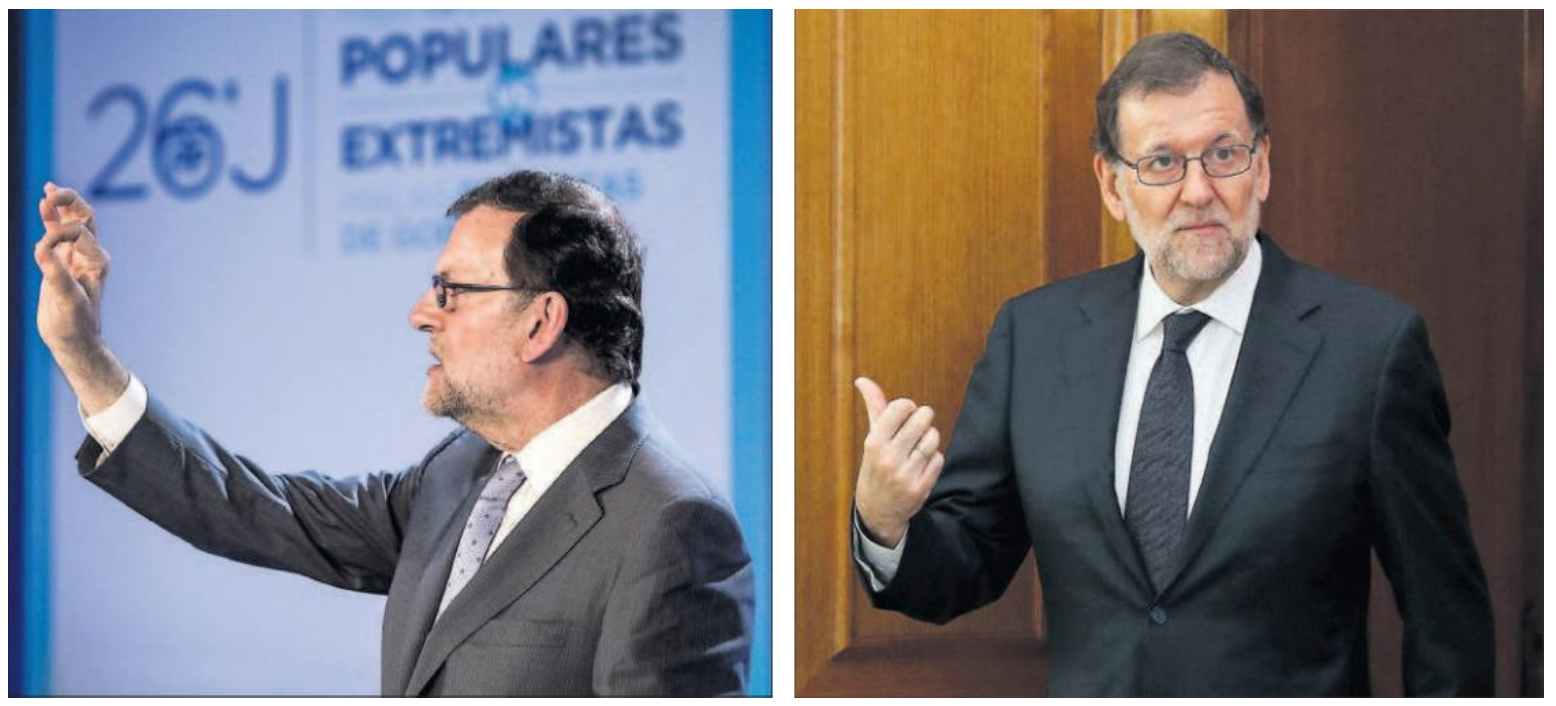

Fig. 6. El País May $20^{\text {th }}$ (Tolo Ramón) \& October $26^{\text {th }} 2016$ (Chema Moya)

The most frequent motif among this group of empty gestures shows Rajoy with both arms wide open and palms facing up, half messianic and half clueless, as shown in Figure 7. Remarkably, despite being ideological rivals on the left/right political spectrum both El País and El Mundo chose the same image for their front page, made even more satirical by the trite slogan in the background: En la buena dirección (On the right track). Opposed to Angela Merkel's commanding I-am-in-control gesture, the Merkel-Raute (resting hands in front of the stomach, thumbs and index forming a diamond), Rajoy's palms-up gesture seems reactionary, like a backward mixture of religious traditionalism (a priest opening his hands to the almighty) and sheer incompetence of the don't-blame-me type (the guilty party claiming it's not their fault or what else could they have done). In fact, those two signifiers are fully apparent in the trajectory between the two El País front pages reproduced here, the first one taken in a political rally in 2015 and the second one belonging to his declaration during a corruption trial for the illegal financing of his party in 2017. In the former, the mouth grimace and the gesture itself seem a rather harmless - parody of a priest giving a sermon, whereas the latter carries the bitter weight of cynicism, with Rajoy questioned in court (the photo was taken from a video screen) and denying the evidence against him. 

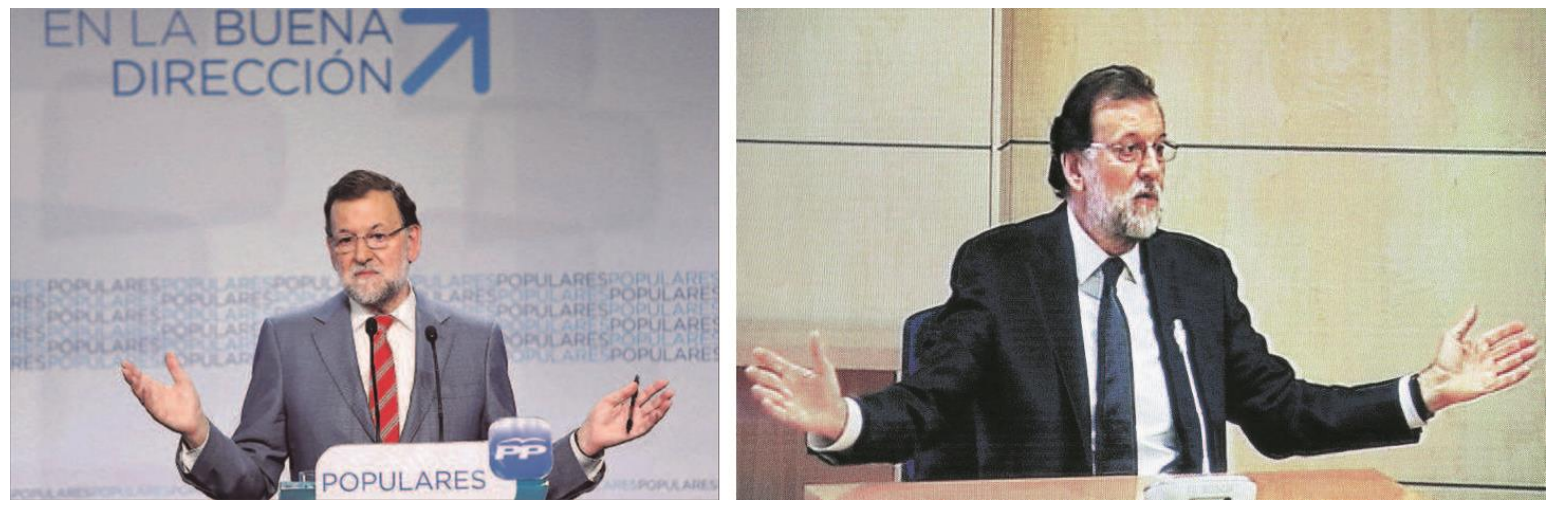

Fig. 7. El País May 26 2015 (Samuel Sánchez) \& July 27 2017 (Chema Moya)

In a context of economical and territorial crisis, when smart politicians tried to avoid gestures tied to religion or any other jubilant manifestation of supreme power (suspicious during austerity policies), Rajoy was repeatedly photographed with his hands up in one of the most traditional of traditionalist gestures, one reminiscent of the indigenous heritage of National-Catholicism dating back to Franco's dictatorship: the image of priests stretching their arms in mass. That outmoded mélange of religion and populism connects with Agamben's (2011a: 180) study of the theological roots of economic and political power, in its discursive gestures, which points to a tension bridging the rituals of institutional authority and religious benediction. This iconic linkage, that Western democracies were supposed to have left behind a long time ago, was reenacted during a visit of Japanese authorities to Santiago de Compostela in May 2014 (Figure 8). The front page connects with century-old practices of photographic satire aimed at political and religious authorities (Kaplan 2017: 7), here exemplified in the liaison between Rajoy's beatific gaze and El Mundo's mocking caption "Rajoy entrusts himself to the Apostle," which combines visual and verbal humour. But beyond the pun itself, what's truly symptomatic is how the religious and political links identified by Agamben are arguably prevalent today in Spain, how the very image of Rajoy could be read as a symbol of anachronism and rigidity linked with religious (which in Spain is often tied to Francoist) iconography. While Shinzo Abe accompanied Rajoy on that day and was photographed behind the statue, it was Rajoy alone who appeared in El Mundo's front page and was satirised visually and verbally. 


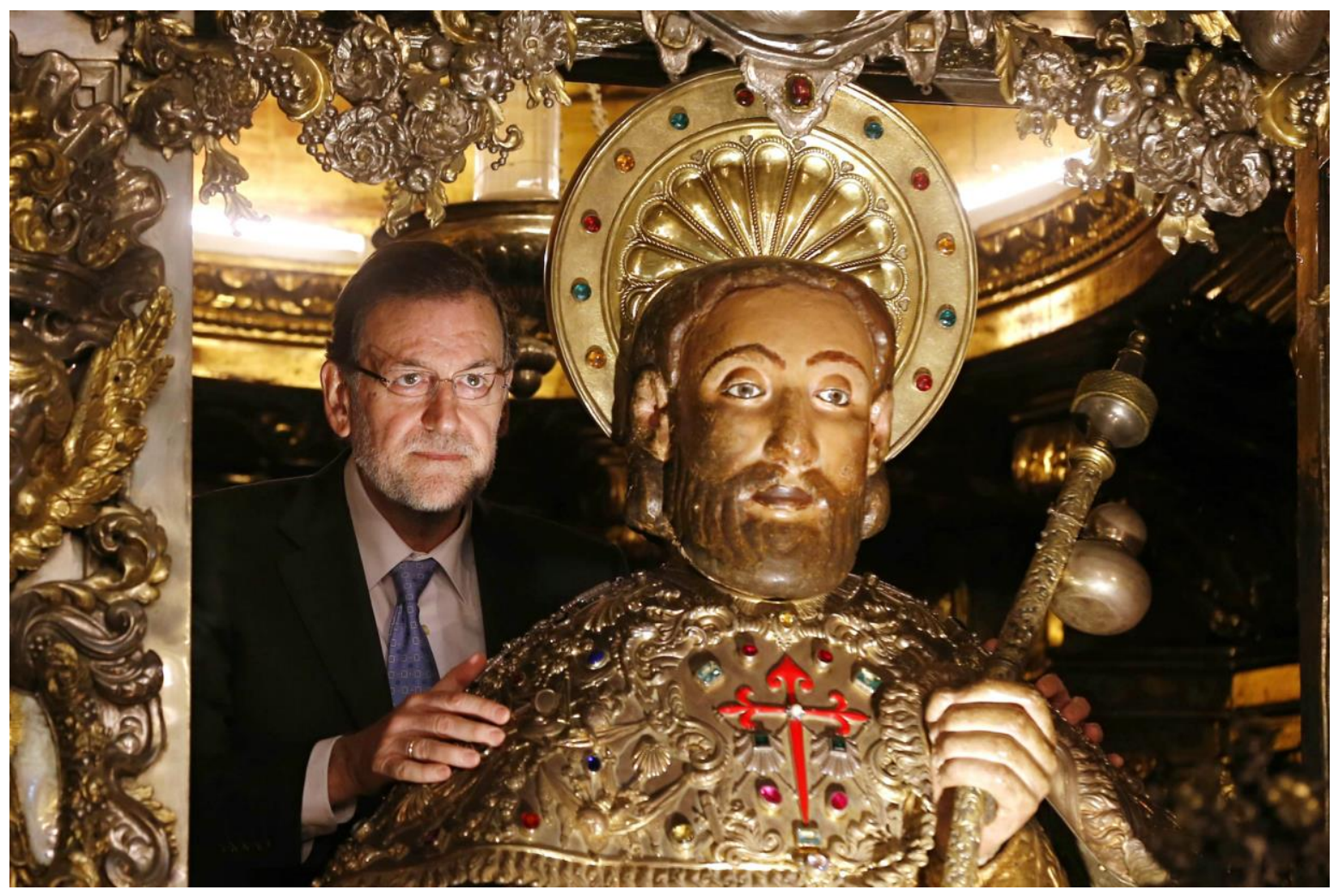

Fig. 8. El Mundo, May $5^{\text {th }} 2014$ (Diego Crespo)

\subsection{Misplacement: odd man out}

Before going deeper into the critical and iconographical analysis in the next section of our article, we should mention a third group of visual motifs composed by photographs of an outof-place Rajoy in public receptions and group photos (with ministers, European leaders or party supporters), where the collective framing of the shot is perturbed by his misplaced gestures and movements, which unequivocally stand out among the crowd (Figure 9). While such photos are sometimes used to portray a more natural and down-to-earth side of politicians, breaking protocol in a controlled manner, the systematic repetition of this motif in front-page photographs from El País, La Vanguardia and El Mundo confirms a tendency to highlight Rajoy's corporal disjuncture. Framing stiff and out-of-place salutes (upper left image), unglamorous irruptions that seem chaotic instead of forceful (upper right image), vulnerable back postures showing lack of agency (down left image), or motion imbalances (down right image). All of which relate to the involvement/detachment binary that Kress \& van Leeuwen (2006: 136) see in the difference between frontal and oblique camera angles, here tied to Rajoy's inability to blend with the collective stillness or movement of the group as a whole. When others are still, he moves, when others move he stands still, often depicted as the odd man out. 

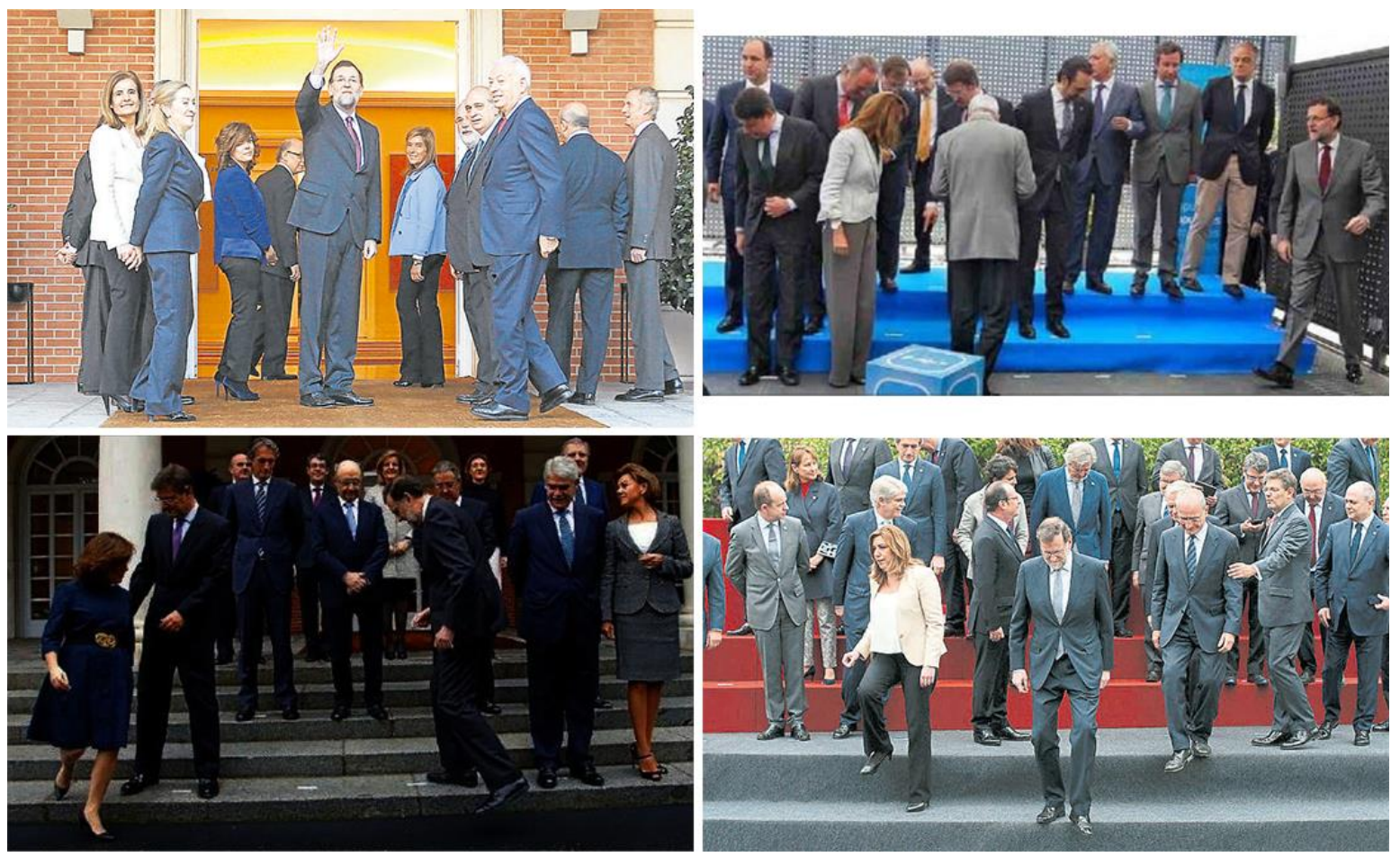

Fig. 9. La Vanguardia Dec. $24^{\text {th }} 2011$ (Emilia Gutiérrez), El Mundo May $28^{\text {th }} 2013$ (José Aymá), El Mundo Nov. $5^{\text {th }} 2016$ (Javier Barbancho), La Vanguardia Feb. $21^{\text {th }} 2017$ (Jorge Guerrero)

We believe that Rajoy's visual misplacements have to do with what Kuipers (2015: 20) calls the relational and situational nature of satire, in her study of the reactions of politicians as targets of public mockery. Different photographers have confirmed to us that in situations such as the ones depicted in Figure 9, when protocol coordinators and advisers want the "right" image to be taken (a prefabricated group shot) to send the "right" message (full agreement), they often wait for moments of imbalance and gestural instability that question the politician's command, in this case the Prime Minister's ability to properly gather the troops. In spite of his efforts to blend in, newspaper editors often chose images that portray the contrary, altering the relational logics of power regardless of it being exhibited in a more relaxed and festive situation (such as the one on El Mundo's front page in November $18^{\text {th }} 2013$ ), or in most dignified portrayals of Spanish institutionalised power (such as the photo in El Mundo's front on October 13 ${ }^{\text {th }} 2017$ ). In the latter, when King Felipe VI himself is pointing to the sky, a classic motif of gestural authority that leads the way for the whole entourage, Rajoy looks to the left in profile, alien to and detached from the command (and the visual perspective) of power. Likewise, in March $7^{\text {th }} 2017$, to picture a meeting of EU leaders in Malta, El Mundo chose an image where Rajoy is looking down to his phone whereas Merkel and May share an attentive and synchronic look, thus stressing his inability to blend in. This does not mean that the other politicians were not mocked in their countries; it simply testifies to Rajoy's visual and functional misplacement, trying too hard or not enough, unable to belong to the "power club" where he is supposed to belong, in what Mitchell (2005: 33) described as a weaker power of images that intertwine desire with impotence. Or rather, it testifies to the reluctance of the press, of the most powerful newspapers in Spain, to let him belong. 


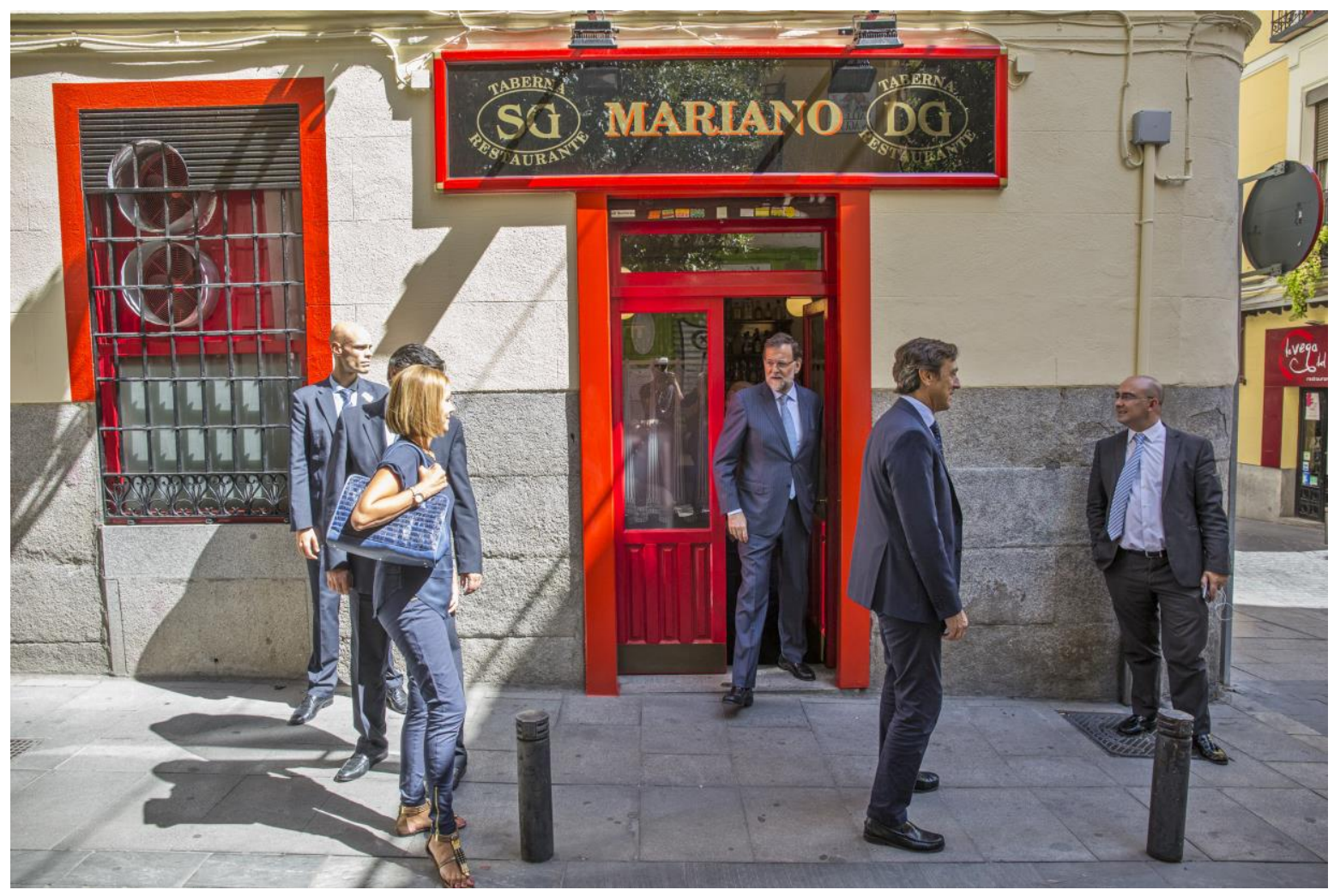

Figure 10. El Mundo, September $15^{\text {th }} 2015$ (Angel Navarrete)

If Foster Wallace (1998: 26) once defined the peculiar humour of Kafka as a kind of door, an impossible door that opens outward and reverses space, the images that best depict Rajoy's proverbial out-of-placeness show him standing on the threshold of absurd and ridiculous doors. Perplexed and lacking any sort of agency, in limbo, as we can see on the satirical front page of El País in May $18^{\text {th }} 2012$, or traversing the door of a Lynchesque red tavern the name of which is Mariano, serving the joke on a silver platter to the editors of El Mundo for the caption: Doblemente Mariano (Doubling Mariano; Figure 10). But, as far as satire and power are concerned, Rajoy's perseverance in attempting to enter the real spaces of command, his robotic determination to open the door of legitimacy (denied by the press), is more dramatic and troublesome than it seems at first glance: "Kafka's authority figures are never just hollow buffoons to be ridiculed, but are always absurd and scary and sad all at once [...] the really central Kafka joke - that the horrific struggle to establish a human self results in a self whose humanity is inseparable from that horrific struggle" (Foster Wallace 1998: 25). Power corrupts and, as we will see in the following pages, what might seem an innocuous smile from a politician can mask the distressing traces of the grotesque.

\section{The layers of photographic satire: power im stillstand}

After grouping the most recurrent visual motifs, it is time to go deeper into the critical and historical implications of Rajoy's humorous photographs, comparing them with the Spanish iconographic tradition, and to do so, we will now focus on another key aspect of Rajoy's photographic satire: his grimaces and facial expressions.

\subsection{Dis/empowering power: Rajoy, El Mundo and Spanish royal portraiture}

Published in the midst of a corruption scandal for the illegal financing of Partido Popular, 
Rajoy's party, the August $2^{\text {nd }} 2013$ front page of El Mundo is one of the clearest examples of how newspaper editors do choose between different options (more or less humorous) before picking a specific photograph to be published, especially in the case of a front page. Rajoy's depiction as an inept and unfit Prime Minister by the editors of El Mundo becomes crystal clear when contrasting both photos: an threatening leader (left image: finger up) and a chimpanzee making funny faces (right image: cheeks down), assertive vs. ridiculous. A visual layout that corresponds with Kress \& van Leeuwen's (1998: 189) interpretation of the left/right placement as a clash between "the Given and the New," or what Booth (1975: 77) called ironic "clashes of style," since Rajoy's facial expressions and gestures are contrasted in the two images: the left one might raise doubts about its satirical intentions, but the cartoonish hyperbole of the second one satirises both. In fact, a few days before this newspaper had unveiled the corruption scandal he was being accused of, publishing a series of leaked Whatsapp messages between Rajoy and the imprisoned treasurer of his party, Bárcenas. The reprint of such incriminatory messages in the front page, above the photos, underlines the power play of El Mundo over Rajoy, juxtaposing a private image of intimacy (the Whatsapp exchange) with two images of public accountability (speaking in congress). ${ }^{1}$

That contrast brings to mind what Benjamin (1968) and Warburg (Didi-Huberman 2016) called the dialectical traces of photography, the way in which a given image can only be interpreted in juxtaposition with other images, not isolated but in a constellation of visual and political tensions that circulate between different historical junctures:

The Dialektik im Stillstand for which Benjamin speaks implies a dialectic whose mechanism is not logical (as in Hegel) but analogical and paradigmatic (as in Plato). According to Enzo Melandri's acute intuition, its formula is "neither A nor B," and the opposition it implies is not dichotomous and substantial but bipolar and tensive: the two terms are neither removed from nor recomposed in unity but kept in an immobile coexistence charged with tensions (Agamben, 2011b: 70).

This is an open and multi-layered dialectic that W. J. T. Mitchell (2005: 25) also underlines in his analysis.

In that sense, Rajoy's photographs carry much more interpretative weight in so far as they bring to mind notable examples of Spanish court portraiture, specially one of the most popular and remembered portraits of Carlos II by Juan Carreño de Miranda, an image that appears in every single text book and is studied - and mocked - in classrooms all over the country, as the perfect visual representation of the King's satirical nickname El Hechizado (The Bewitched; Figure 11). Not so much because the faces and the eyes look similar but because the simple mention of Carlos II in relation to Rajoy points to the problem of satirical attribution, that is, to what extent it becomes impossible not to interpret their images as satirical (bewitched powers) once we picture them together, willingly or not. Far from being a gratuitous comparison, we have juxtaposed both portraits because the founder and former chief editor of El Mundo, Pedro J. Ramírez, explicitly mentioned Carlos II in his satirical attacks against Rajoy (as seen in one of his editorials, analysed in section 4.2.).

\footnotetext{
${ }^{1}$ The image cannot be reproduced here, but it is accessible at https://www.libertaddigital.com/fotos/portadasde-el-mundo-espana-1006995/02-08-2013-rajoy-atrapado-por-rajoy.jpg.html
} 

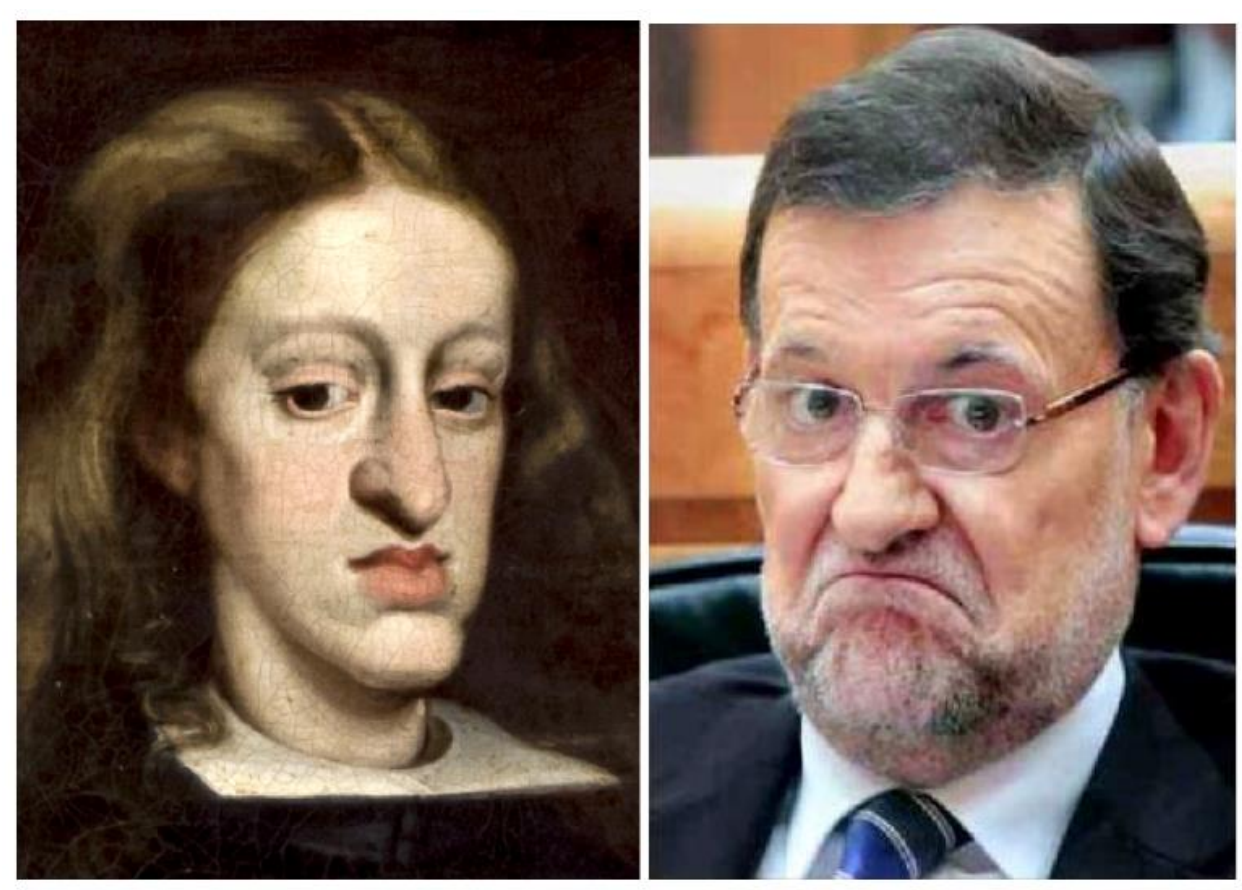

Fig. 11. Portrait of Carlos II (Carreño de Miranda) / El Mundo August $2^{\text {nd }} 2013$ (Antonio Heredia)

While El Mundo's use of satire is undeniable, Carreño de Miranda's intentions when portraying his majesty may or may not have been satirical, but even so, the possibility of satire was most certainly there, surrounding the image im Stillstand, as proven by the existence of special committees that veiled for the "proper" depiction of the Royal Family in every court painting of the time. Velázquez himself, who a few years before had painted several portraits of Felipe IV, The Bewitched's father, was appointed as a member of those proto-censorship committees that "examined the decorum of royal portraits" (Harris 2003: 86), assessing up to 84 paintings and then ordering that the heads should be repainted according to the fidelity and dignity deserved by monarchs (Brown 2008: 111). The mere existence of those practices back in the $17^{\text {th }}$ century shows that the question about what can be considered dignified or satirical is key when it comes to visual representations of power. And in Rajoy's case, his depiction with laughable and ridiculous facial expressions became a trend, as proven by a photo series from the awardwinning photographer Daniel Ochoa de Olza for Associated Press published in January $11^{\text {th }}$ 2012, which triggered a heated debate about the limits of photographic satire.

The problem of intentionality and agency, from the perspective of those who produce or select an image, also links Rajoy's photographs with previous strategies to represent and satirise power in Spanish royal portraiture. Taking a step forward after Velázquez, as a court painter Franciso de Goya hinted of a sceptical vision of power through his down-to-earth royal portraits. The ambiguity of his paintings, noted by Ortega y Gasset (1983) as the peculiar carácter equívoco (equivocal nature) of his art, can be traced back to the works in which Goya performed not only a psychological approach to his models, but also projected on them his own political concerns. The glorification of the monarchy, a trend in many court paintings, was undermined by Goya through a much more prosaic representation, noticeable in the glances of those depicted. In his painting La familia de Carlos IV (1800), an oeuvre in which Goya emulates Velazquez's gesture in Las Meninas (1656) by positioning himself presumably portraying the royal family, "the King himself looks kindly in a nondescript, almost simple-minded way" (Hofmann 2003: 170). This satirical approach to power, still within the subtle margins of decorum, was more noticeable when Goya painted Fernando VII of Spain, self-proclaimed "The 
Desired One." His contempt for absolutism and his mistrust for Fernando VII can be observed in the way Goya painted Fernando's face, with the same goofy stare whether being suited with the royal cloak or a military uniform: a prominent chin, tightly pursed lips and eyes wide open: a gaze without the dignity expected from a king. Not by chance, the photojournalist who took Rajoy's photo in Fig. 12 underlines the need to depict the powerful in critical ways, rejecting to take the kind of lenient, idealised and prefabricated photo that political advisers want for their leaders.
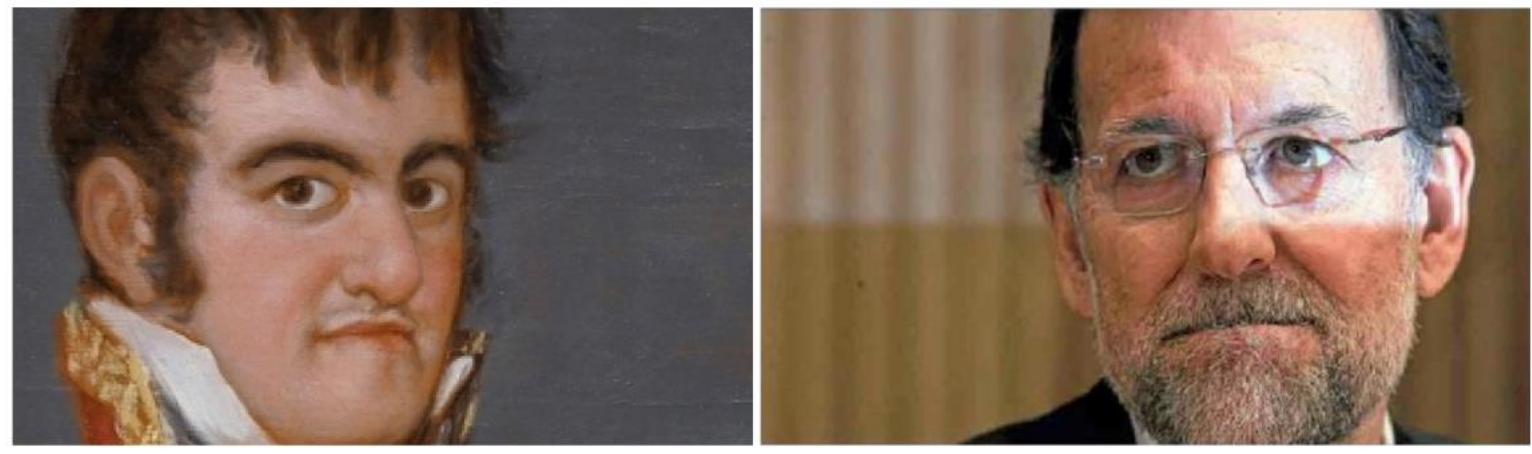

Fig. 12. Goya's Fernando VII en un campamento / El Mundo, January $11^{\text {th }} 2012$ (José Aymá)

The bad relationship between Goya and Fernando VII, which no doubt influenced his pictorial depictions, ended when the King named Vicente López Portaña first court painter. Not by chance, El Mundo's founder and chief editor at the time, Pedro J. Ramírez, also had a bitter antagonising relationship with Mariano Rajoy, to the point that he was removed as director of the newspaper in January 2014, reportedly as a result of the huge governmental pressures from Rajoy's cabinet. While the complexity and distinctiveness of Goya's craft could not be further away from the blunt editorial line of $E l$ Mundo back then, we believe that certain satirical devices employed in the selection of Rajoy's front-page photographs nevertheless relate to the painter's ability to mix the real and the grotesque, a kind of eerie humour that Baudelaire (1981: 238) summarised like this:

Goya is always a great artist, often terrifying. To the gaiety and joviality, to the Spanish satire of the good old days of Cervantes he adds a much more modern attitude of mind [...]. The great virtue of Goya consists in creating a monstrous kind of verisimilitude. His monsters are born viable, harmonious. No one has dared to go further than he in making the absurd appear possible.

\section{IMAGE DENIED BY THE NEWSPAPER}

Search "rajoy rio umia" in your browser

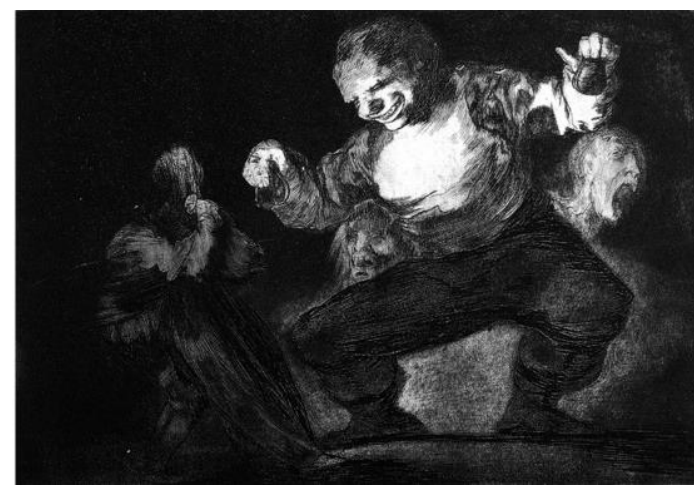

Figure 13. El Mundo, July 27 2015 front page / Goya's Disparates, 4 - Bobalicón, 18151819 
Baudelaire's description of a viable monstrosity, the absurd made possible, resonates in the disturbing image of Rajoy emerging from the depths of river Umia, half-naked and smiling, like Goya's Bobalicón in Fig. 13. Beyond superficial similarities, what makes El Mundo's choice of that particular image more grotesque is the way in which it re-signifies other recurrent photographs of Rajoy smiling as dark and gruesome. The kind of awkward but apparently harmless smile so frequent in Rajoy's photos is reinterpreted as something deeply problematic, an image intimately related to and deformed by power. The ridiculous becomes the grotesque, satire borders nightmare, and the photographic tensions between spectacle and surveillance that Sontag (1977) talked about are multiplied because Rajoy is looking directly to the camera: we laugh at power, power laughs back. Tellingly, the newspaper that owns the series of photos of Rajoy bathing at river Umia, La Voz de Galicia, declined to allow the non-profit reproduction of the image within this article, and refused to offer any reasons explaining why. That reaction, the opaque blocking of portraits of the powerful, confirms that the image-control function of the $17^{\text {th }}$ "decorum" committees is still prevalent today, but now it's not royal officials who implement it but newspapers and media groups that support certain politicians and political parties (such as La Voz de Galicia with Rajoy) to the extent of denying non-profit academic quotation.

Needless to say, Rajoy's river photograph fell within the image act (Kress \& van Leeuwen 2006: 117) constructed by El Mundo in its front pages, the goal of which was to undercut his power juxtaposing the satirical and the grotesque. In most images where Rajoy appears gazing towards the camera (such as the ones in section 3), almost looking at us, humour takes precedence over power, and there is no trace of the commanding distance that, according to Berger (1972: 97), characterised the look of truly powerful men in his analysis of Holbein's The Ambassadors:

How do they look at the painter - or at us? They look as though they are looking at something of which they are not part [...]. The gaze of the ambassadors is both aloof and wary. They expect no reciprocity. They wish the image of their presence to impress others with their vigilance and their distance.

Nothing could be further from Rajoy's weak and gullible stare as depicted across our 2011-2017 archive of front pages, especially in the ones from El Mundo, thus confirming that the Fourth State' satirisation of power is also a way of exerting power.

\subsection{Rebranding satire as parody, when politicians (learn to) mock themselves}

It is time to focus on how Rajoy and his cabinet ended up using his satirical depiction as a mediocre leader for their own benefit, turning it into a victim narrative that transformed (or attempted to transform) the Prime Minister's satirised lack of wits into a positive, down-to-earth, plain quality of the "average Spaniard" during the 2015 elections. This brings us to the second critical question about the self-conscious and often rehearsed performativity of politicians in contemporary societies, which in Rajoy's case involved a deliberate reversal of superiority humour theories making him look like the innocent prey of the Spanish press: a way for politicians to "neutralise the possibility for satirical critique" (Higgie 2017: 73) by shielding themselves in auto-parodical armour. Following Hutcheon's (2000: 29) theories on the stylistic nature of parody, we believe that after years of mockery in the front pages, Rajoy's cabinet and image advisors probably decided to rebrand his "comical style" by transforming the newspapers' satirical attacks into a sort of pre-emptive self-parody. To deactivate the media's satire (its ethics and moral) Rajoy learned to "impersonate" himself in openly stylised ways.

Perhaps knowing that he had already lost the face and dignity a proper Prime Minister is supposed to show, Rajoy spent the general election campaign indulging in banal and self-parodic 
behaviour to win the compassion and sympathy - that is, the votes - of old people in rural areas of the country (as proven by multiple campaign mottos and photos). In other words, he practiced the kind of populist anti-politics analysed by Rolfe (2017: 45) in his study of political satire in Australia, which "present the untainted virtue of political inexperience against the endemic iniquities of the political game." Two years after mocking him with the Whatsapp corruption front page, when El Mundo and other newspapers chose to publish images of Rajoy playing dominoes in a retirement home or playing table football with Bertín Osborne (Figure 14), humour was not really working against his public image as satire but for his campaign strategy as parody. When the target of political satire embraces his comicality, as a parody of style, exaggerating his own gestures and engaging in self-deprecating humour as Rajoy did in 2015, satirical critique not only becomes redundant but risks being accused of cruelty and elitism, entering a humour trap.

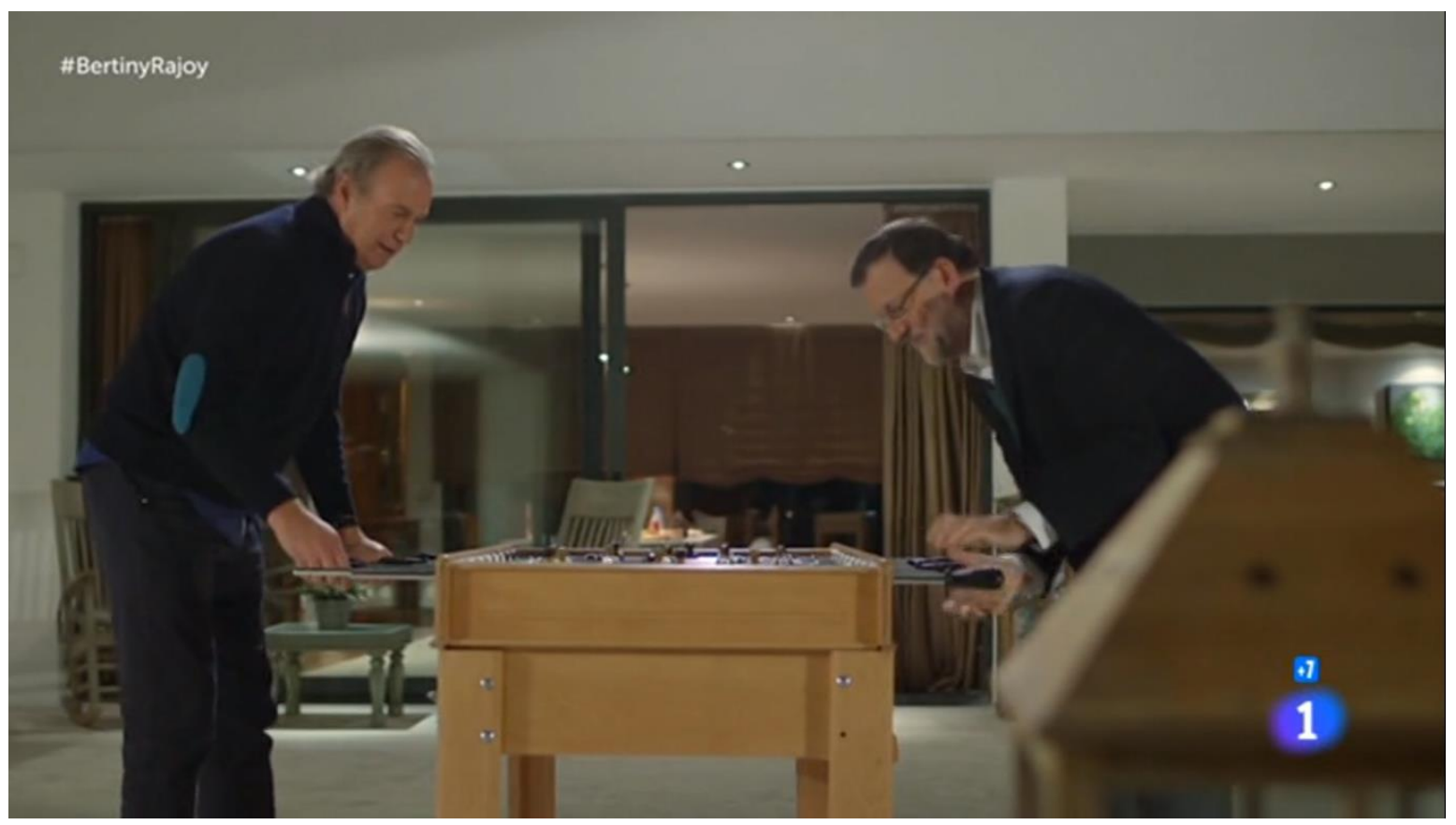

Figure 14. Frame from a public TV program ad, used in El Mundo's December $2^{\text {nd }} 2015$ front page

The aforementioned "Rajoy trapped by Rajoy" August $2^{\text {nd }} 2013$ El Mundo front page, with the Bárcenas Whatsapps, and the one in December $2^{\text {nd }} 2015$, combining dominoes and table football, both used a binary photomontage, but the differences could not be more telling. In the former, the camera pictures are extremely close so that Rajoy's gesture and facial expression remain isolated, in the kind of image composition that Berger read as intrinsically comical (2013: 95), and the satirical intents of the newspaper were effective. Conversely, in the latter, the overtly comical choice of images that diminishes Rajoy from a bird's eye view on the left image and in profile on the right, seems rather aligned with his campaign strategy of selfdeprecating humour: his playful smiles looking more like self-conscious automated gestures than as satirical depictions (the fact that he appears playing dominoes and futbolin, namely two traditional popular games, looks premeditated). Arguably, the more self-parodic Rajoy's behaviour became, the less pointy and more homogeneous the front pages ended up being, as exemplified in the two identical images that illustrated the cover of $\mathrm{El} \mathrm{Mundo}$ and $\mathrm{La}$ Vanguardia in August 20 2015. 


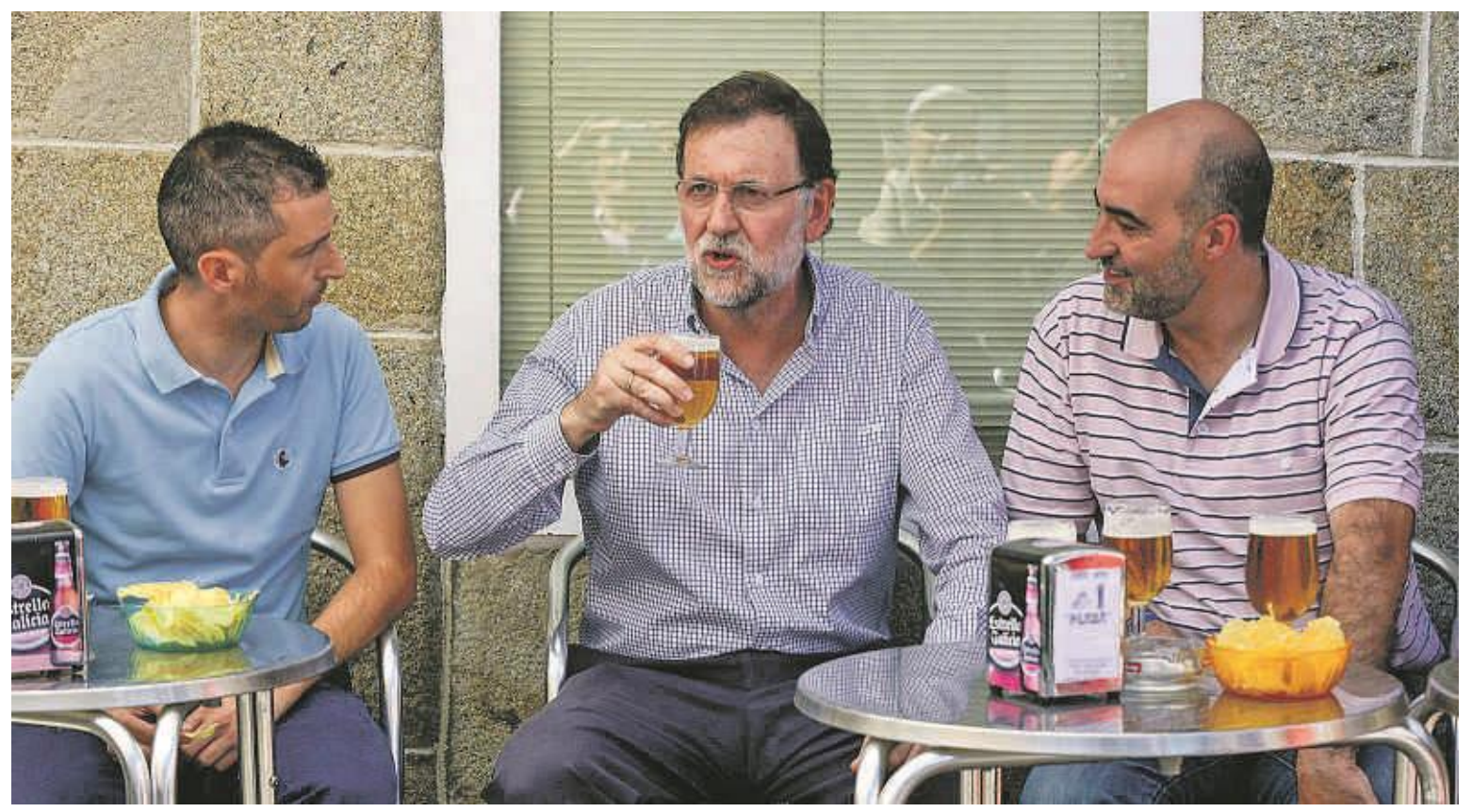

Figure 15. El Mundo \& La Vanguardia, August 20 2015 (Brais Lorenzo)

The image of Rajoy holding a glass of cold beer in the heat of the Spanish summer, with two paisanos (country folk) in an unpretentious down to earth terrace, seems completely predesigned by his campaign advisors, as the photographer himself confirmed to us. It was a photograph meant to be taken, as proven by the mirror reflection in the window behind them, showing a group of photojournalists (with professional cameras) and bystanders (with mobile phones) waiting to immortalise the supposedly spontaneous moment. Even the image's placement on the centre of both front pages confirms Arnheim's (2009: 196) of-cited theory about the focalisation of power in centred compositions, which Kress \& van Leeuwen (1998: 196) link with religious art. When compared with previous examples, the image of Rajoy drinking beer on vacation seems well within the controlled limits of self-conscious and pre-emptive humour (a typical Spanish image of benevolent parody: cold beer in the summer), and therefore, oceans apart from the satirical grotesque photos analysed before. The moral critique implied in satire gives way to a merely stylistic parody, devoid of punch. 


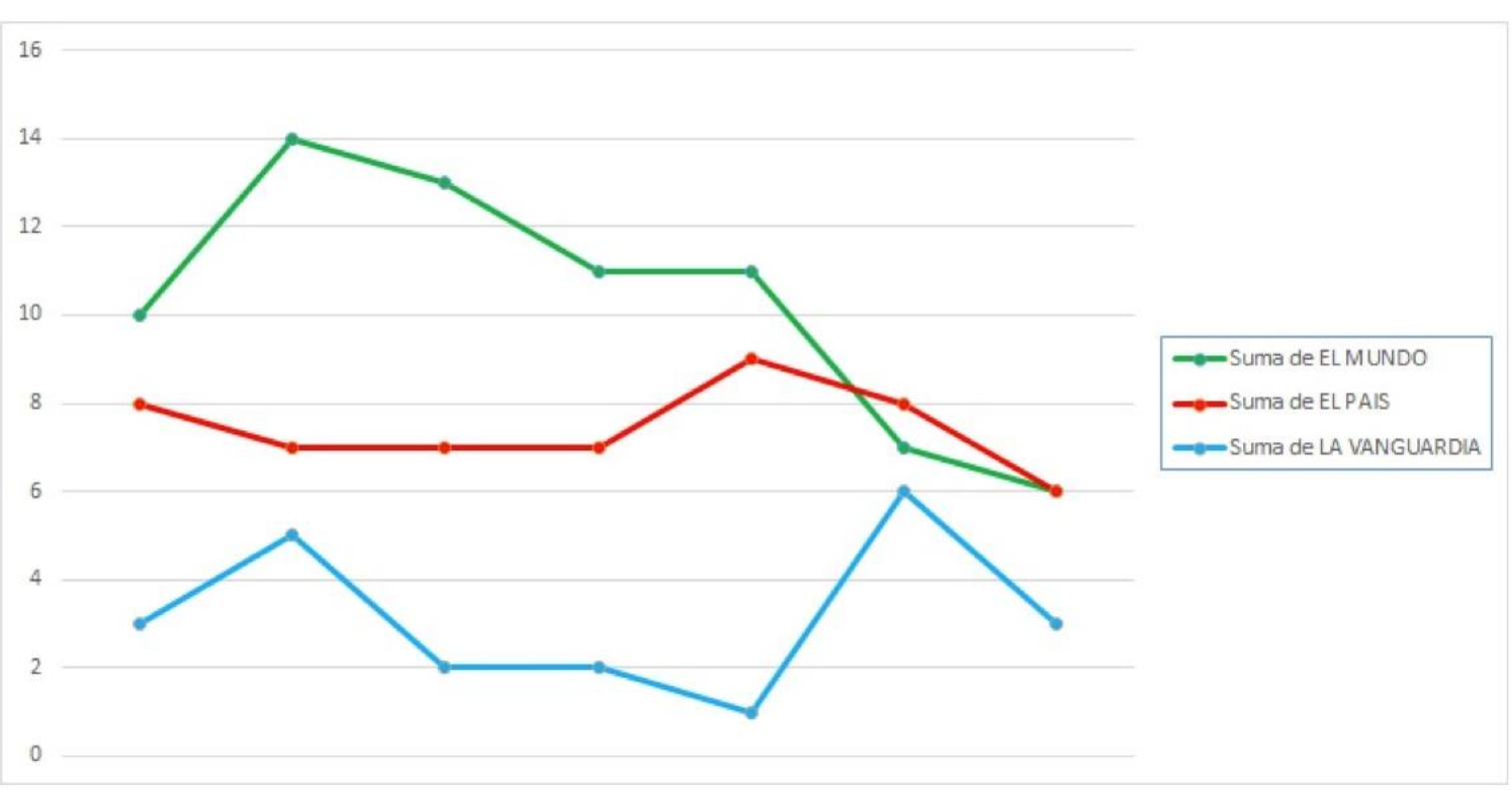

Figure 16. Historical distribution of the satirical front pages between 2011 and 2017

While any quantitative interpretation of our sample should be cautious (determining what's satirical and what's not implies a margin of error), we have found a considerable decrease in the percentage of Rajoy's humorous depictions in front pages after 2015, when he learned to repurpose satire into parody for his own benefit. El Mundo, for instance, that included up to 14 overtly comical photographs of Rajoy in 2012, gradually slowed down the satirical pace to the point of publishing "only" 6 in 2017, that is, less than half (Fig. 16). There are historical and contextual reasons for that decrease, such as the uncertainty and weariness provoked by the difficulties to form a stable government after the December 2015 elections (Rajoy lost $33 \%$ of the votes but still won), to the point of having to repeat the national elections in June 2016 (Rajoy increased votes by $8 \%$ compared with 2015). But to measure the success of his defensive auto-parodic strategy, it should be noted that those elections took place during the biggest corruption scandal of illegal financing in Spain, with ample proofs against the governing party being published daily. Therefore, only losing $33 \%$ of the votes was more a victory than a defeat for Rajoy, even if he lost the absolute majority he had enjoyed since 2011. Pre-emptive selfparody sure helped him to diminish the damage, because after all, what else did he have to do to actually lose an election?

The fact that El Mundo, but also El País and La Vanguardia, ceased to publish as many humorous portraits of Rajoy in 2016 and 2017, was also tied to the urgency of more critical matters such as the territorial crisis due to the claim for independence in Catalonia, or the social pressures of an economic crisis that still generated fear and insecurity across the country. Not to mention the fact that, like jokes, visual gags age, and overusing one particular motif - such as Rajoy's smile or gaze - can undermine its comical efficiency. But still, we believe that in terms of the liaisons between power and humour it is very significant that Rajoy, whose biggest virtue was considered to be resilience, managed to absorb satirical critique by taking back control of his humorous persona, thus countering the power play of media conglomerates against his presidency. The dis-empowering visual depictions we analysed before ended up being a bit more re-empowering than expected. In that sense, the image that better explains the legendary ability of Rajoy for taking satirical punches and turning them around as self-parodical blows is that of the estafermo or the quintain (referred to in section 3.1). Rooted in the Quixotic tradition, Rajoy's depiction as a mannequin sandbag figure that revolves after being hit, waiting to be tilted, was coined by El Mundo's former chief editor Pedro J. Ramírez, who got fired for 
satirising too much:

Only the estafermo moves by being still. That is the kind of he, or more likely the it, that is governing us: a weathercock handled by the wind, a tuning fork reverberating external sounds, a gong where an alien mallet hits, a straw doll in the political joust that works with the same fluke as a punching bag and as a bludgeoning stooge [...]. An artifact, standing up like a traffic cop, with his baton and his whistle, who attacks from behind when you least expect it

(Ramírez 2014, our translation from Spanish).

As far as our analysis is concerned, two key issues surround such symptomatic text. The fact that it was not accepted for publication in El Mundo (Ramírez still worked as a collaborator after being removed as chief editor) and had to be published somewhere else, exemplifies a kind of censorship - the estafermo is above all, an image - reminiscent of the royal "decorum committees," where Velázquez and others assessed pictorial representations of power. But, more importantly, the fact that Ramírez's text starts with a Baudelaire quote concerning the caricaturesque image of Gérard de Nerval, taking his locust for a walk, and the fact that it references the moronic portraits of Carlos II The Bewitched later on (the one quoted in Figure 11), both demonstrate that the ideological and iconological Dialektik im Stillstand that Benjamin and Warburg (Agamben 2011b: 70) had in mind is real and has shaped the relation between humour and politics for centuries. It does not seem to be a coincidence that Carlos II and Rajoy, both rulers satirised as unfit and utterly inept, ended up being vanishing points of their own historical periods: the former as the last, heirless Habsburg ruler of the Spanish Empire, triggering the Succession War; the latter as the first and only impeached Prime Minister in Spanish democracy, triggering the country's worst constitutional and territorial crisis since the Civil War.

\subsection{Panem et circenses: grotesque humour and political overexposure}

It is precisely in this juncture between different mechanisms of power, the Government on the one hand and the Fourth Estate on the other, where the complex and often contingent nature of political satire comes to the fore, pointing back to the third question posed at the Introduction: audience interpretation and response. While some examples within the sample could be interpreted as benevolent humour, a lighter and cartoonish portrayal of Rajoy that does not necessarily imply satire (the photographers we have interviewed for this research underline his down-to-earth personality), it is important to keep in mind that his tenure was full of corruption scandals and blatant political lies that severely damaged the institutional and judicial legitimacy of Spanish democracy (Pérez-Royo 2020). After all, as funny and light-hearted as they may seem, estafermos have always been weary and gruesome pieces of machinery, from medieval jousts to the current political arena. There is always a limit to the amount of violence a mannequin can withstand, and likewise the amount of satire and cynicism an elected politician can rebrand. During the last days of the 2015 campaign, a young man violently attacked Rajoy in Pontevedra and caused him minor but still gross and visible wounds, literally re-enacting the estafermo image that Pedro J. Ramírez had been constructing on the front pages of El Mundo in the previous four years. A disturbing image rooted in iconography, which goes back to Baudelaire's (1981: 237) comments on Goya's dark humour:

Light and darkness play in and around these grotesque horrors [...]. All the hideousness, all the moral filth, all the vices conceivable to human minds, are writ large on these faces, which, in accordance with a frequent habit and an inexplicable technique of the artist, are halfway between man and beast. 

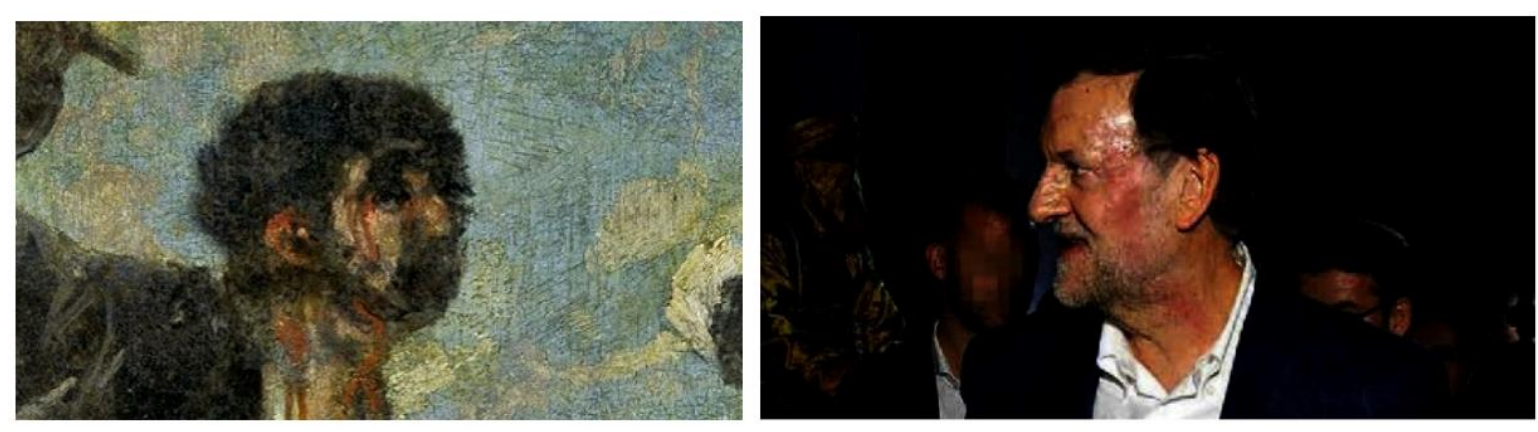

Figure 17. Goya's Fight with Cudgels (detail) / El Mundo, December $17^{\text {th }} 2015$ (Mónica Patxot)
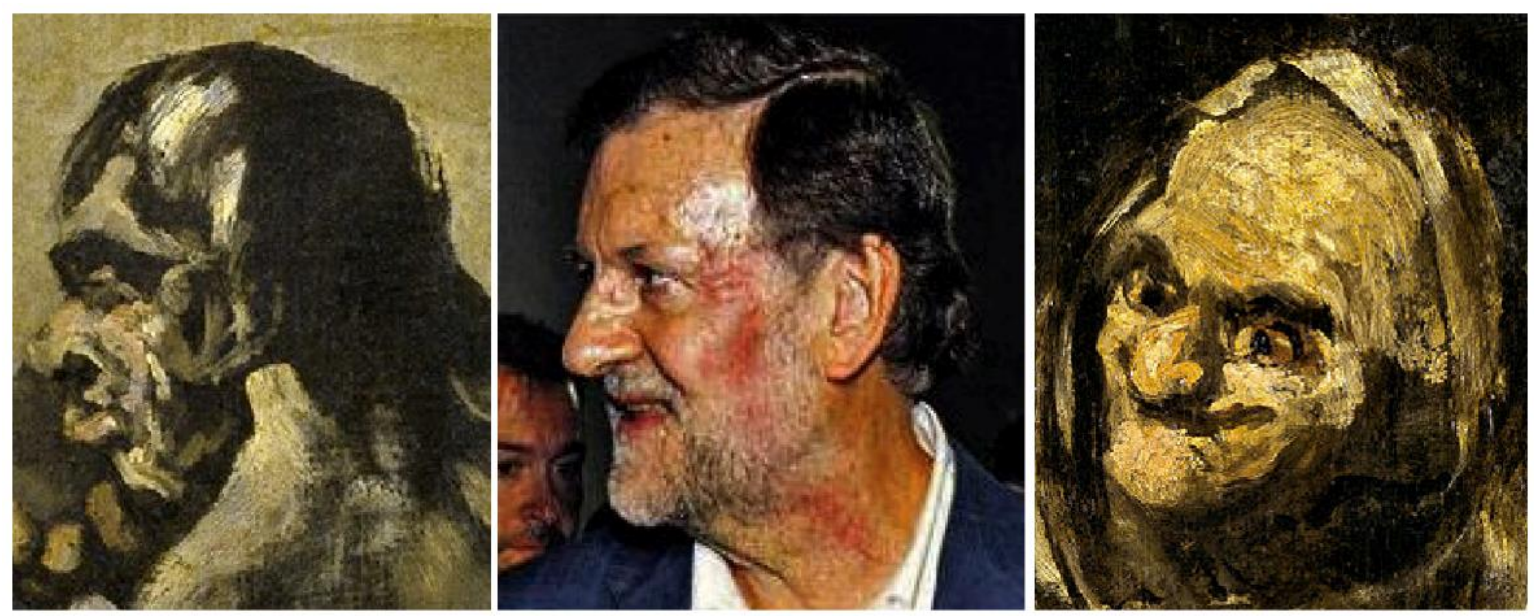

Figure 18. Rajoy's photo between details from Goya's The Fates \& The Old Ones Eating Soup

The three newspapers, El País, El Mundo and La Vanguardia, published grotesque portraits of Rajoy trying to smile artificially after the incident, that in spite of not having a satirical intention reverberate with hundreds of earlier images where the same expressive trait dominates the composition: his awkward smile, half resilient and half clueless. Seeing the gruesome pictures of that aggression, the referent that comes to mind is Goya's Fight with Cudgels, one of the fourteen paintings known as Pinturas Negras that belong to the later years of his life, between 1819 and 1923, especially because of the red contusion that appears in profile on both images, with traces of blood falling from the eyes down to the cheek and ending in the neck (Figure 17). But we find a parallel connection with other black paintings such as The Old Ones Eating Soup and The Fates (Figure 18), where the grotesque depiction of old decrepit faces is enhanced by their mortuary smiles. With old age and traditionalism being two of the key signifiers of Rajoy's front-page satires (unfit to keep up with the times: the VR goggles, the estafermo, etc.), such a grotesque juxtaposition exposes sociological and generational tensions of media reception in the Spanish electorate.

How did such a direct and continuous mockery of a democratically elected presidente shape the perception of democracy in the country? If we risk a hypothesis using Frye's (1957) memorable way of relating the four main literary modes (comedy, romance, tragedy, satire) with the cycle of the four seasons (spring, summer, autumn, winter) in Anatomy of Criticism, it seems that satirising Rajoy in such a blatant way, more harshly and frequently than previous Spanish Prime Ministers, ended up blurring the limits between political satire and hate speech, comedy and tragedy, playfulness and real danger. Taking into account that Rajoy had been systematically depicted as an old school politician with backward methods (satire), and that in 
the 2015 elections he gladly played the role of an old school politician with backward methods (parody), it is fair to ask to what extent he was physically attacked for behaving like an old school politician with backward methods (drama), all of which probably reinforced the image of Spain as an old school country with backward methods.

Moreover, it is worth considering if the consequences of it all, Rajoy's unprecedented impeachment but also the climate of political disbelief and resentment against official institutions in Spain, was not partly a result of the various humorous strategies employed by powerful media conglomerates, and by the government itself, to advance their political agendas no matter what. Akin to Holm in his study about the dangerous liaisons between humour, populism and neoliberal discourses (2017), it is fair to ask if the humorous images circulating through social media along with the current transformation of politicians into influencers (Casero-Ripollés 2020) may have contributed to the increasing mistrust and cynicism towards Spanish democracy as a whole. A particularly dangerous game in a peninsula with fragile democratic foundations, the only European region where Fascism won and prevailed after the Second World War, with total immunity, policing the uses of both power and satire for decades.

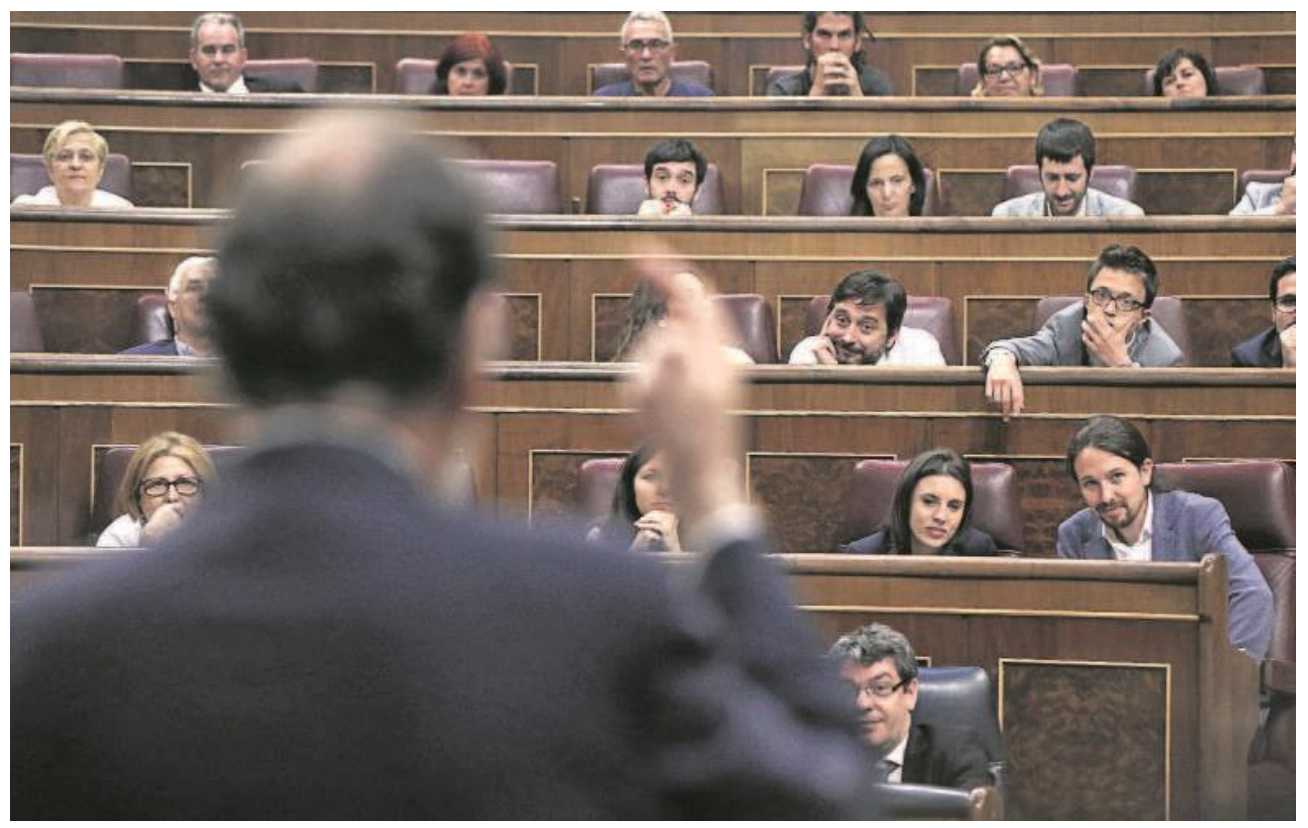

Figure 19. El País, June $14^{\text {th }} 2017$ (Uly Martín)

The cover photograph from El Pais in Figure 19 exemplifies very well the faded comedic role that Mariano Rajoy acquired in the last months of his tenure, before the impeachment. Notice the image's point of view from behind him, that conveys fragility in visual terms (Kress \& van Leeuwen 2006: 138), along with the futility of his gesture and the blurring of his silhouette, shifting focus from him to his audience, as if he was about to vanish (precisely what happened after being impeached). More importantly, however, the picture emphasises the view of the Congress benches situated facing him, with nine or ten MPs smiling or laughing in front of Rajoy, including Pablo Iglesias, head of the opposition left-wing party Podemos, his ideological and generational nemesis. Humorous exchanges are, of course, frequent and even desirable in parliamentary houses, which after all are spaces for human interaction (wit being part of it). But the visual layout of this particular front page underlines how Rajoy's depiction as laughable had become ingrained in the Spanish public imagery, to the extent that Congress itself is depicted like a comedy club, where elected representatives laugh and make others laugh. The question is what happens when the spaces of democratic legitimacy are framed and consumed as mere entertainment? 
This kind of banal mediatisation of the political sphere goes back to Sontag's (1977) point about the interplay of spectacle and surveillance in mass media photographs, which lies in the core of Agamben's actualisation of Debord's The Society of Spectacle (1970) in his book Means Without Ends (2000), where he unmasks the communicative alienation of politics in the contemporary world. In his critique of media hegemony, Agamben also questions the category of satire itself after Karl Kraus and Debord, its scope and efficiency in a society where the social and ideological structures that used to make satire effective are totally mediatised, lost among millions of commodified images that saturate the public sphere. He posits that the substitution of $19^{\text {th }}$ century words such as people or general will with new words from mass media such as public and public opinion, marks a shift from the domain of action and political protest (wilful agency) to consumerism and spectacle (taming reception):

Debord's discourse begins precisely where satire becomes speechless. The ancient home of language (as well as the literary tradition on which satire is based) has been, by now, falsified and manipulated from top to bottom [...]. What prevents communication is communicability itself; human beings are kept separate by what unites them. Journalists and the media establishment (as well as psychoanalysts in the private sphere) constitute the new clergy of such an alienation of the linguistic nature of human beings [...]. Contemporary politics is precisely this devastating experimentum linguae that disarticulates and empties, all over the planet, traditions and beliefs, ideologies and religions, identities and communities.

(Agamben 2000: 84)
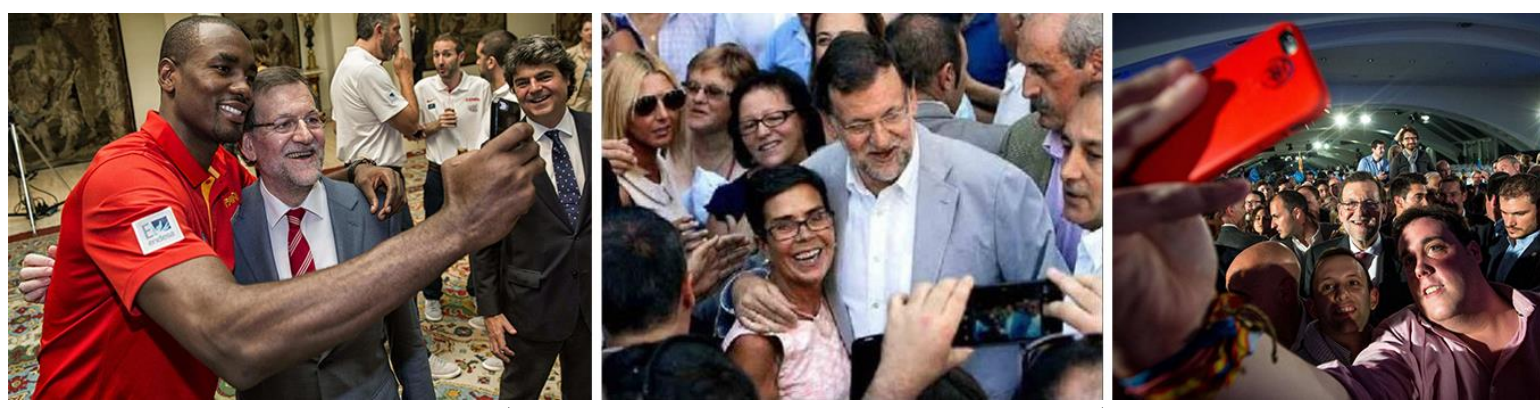

Figure 20. El Mundo August $1^{\text {st }} 2014$ (Alberto Nevado), September $1^{\text {st }} 2014$ (Rosa González) \& December $19^{\text {th }} 2015$ (Gabriel Gallo)

While we are not as openly pessimistic as Agamben, specially concerning what readers and viewers can do with the images they consume nowadays, it is true that a close look at our 20112017 front page archive confirms that the common satirical element of most images, Rajoy's awkward smile (the one that goes back to Carlos II and Goya), was also a key trait in his problematic relation with the most spectacular form of contemporary portraiture: selfies. In that sense, the front-page photos included in Figure 20 problematise many of our previous assumptions throughout the article, pointing to one of the biggest challenges for any visual analysis dealing with contemporary media: overexposure, that is, the layering of images over images. The way in which all images today are constantly mediated by and piled on millions of other images. If, according to Agamben (2000: 79, 94, 128), the key problem today is not the power of an image but the constant flow of mediated images, that is, the inability of images to acquire power and political agency due to perpetual overexposure, we ask to what extent is the proliferation of so many satirised images of power diminishing the satirical punch of images per $s e$ ? In other words, when the awkward smiles of a corrupt politician are the new normal, and front-page photographs are photographs of photographs, is there anything left for the camera to wait for, look through, and maybe satirise? Such questions require further research, and new articles focused on them, but before closing with the conclusions it is worth asking to what extent such overexposure, the constant flow of images, might end up numbing audiences, 
shielding the corrupt, and rounding the sharp edges of satire.

\section{Conclusions and further research}

In an attempt to prove how Spanish newspapers satirised Rajoy in their front pages images, from a relational and culturally specific perspective, we have examined a series of visual motifs and iconographical strategies blending photography and humour: from the deliberate framing of laughable grimaces and gestures to the misplacement of the protagonist inside ensemble shots, as well as the juxtaposition of contradictory elements (objects, postures, gazes) and peculiar facial expressions within the frame. We have established how power and humour juxtapose in a dialectical tension, according to specific visual choices (motifs, camera angles, gestural constants) made by photographers, journalists and editors, thus reflecting the agendas of media conglomerates, institutions and political parties.

Comparing front page photos with key works of the Spanish iconographic tradition, a parallel has been established between historical and contemporary approaches to satire that deal with the representation of powerful figures, pointing to mechanisms of censorship and to pressing questions about how power is constructed or criticised in visual terms. How can the position, timing and framing of a photograph convey satire? Which economic, social and political interests condition the selection of a particular image by different newspapers? Can politicians rebrand humorous motifs for their own benefit, transforming the media's satirical attacks into self-parody? And, to what extent is the practice of photojournalism today connected with the lessons and challenges of art history and iconography?

Finally, having examined only photographs that appeared on a database of 7,500 front pages of El País, El Mundo and La Vanguardia between 2011 and 2017, we still feel that our study could benefit from further research about the re-appropriation and spreadability (Jenkins et al. 2013) of those same images as memes, a complex and fascinating topic that we could not address here. Hopefully, in spite of its limitations, these lines will foster new debates about the key role of images and visual motifs in our societies, without forgetting humour and critique.

\section{Acknowledgements}

We would like to close by thanking the different photographers, photojournalists and graphic editors that so generously responded to our research queries, offered key insights during interviews, and authorised the non-profit reproduction of their photographs: without them this article could have never been conceived or published

\section{References}

Agamben, G. (2000). Means without End: Notes on Politics. Minneapolis: University of Minnesota Press.

Agamben, G. (2007). Profanations. New York: Zone Books.

Agamben, G. (2011a). The Kingdom and the Glory. For a Theological Genealogy of Economy and Government. Stanford: Stanford University Press.

Agamben, G. (2011b). 'Nymphs', in Khalip, J. \& Mitchell, R. (eds.), Releasing the Image. From Literature to New Media. Stanford: Stanford University Press.

Arnheim, R. (2009). The Power of the Centre: A Study of Composition in the Visual Arts. California: University of California Press.

Balló, J. \& Bergala, A. (eds.). (2016). Motivos visuales del cine. Barcelona: Galaxia Gutenberg. 
Banks, M. \& Mayer, V. (2009). Production Studies: Cultural Studies of Media Industries. London: Routledge.

Banks, M. \& Mayer, V. (2015). Production Studies, The Sequel! Cultural Studies of Media Industries. London: Routledge.

Barthes, R. (1981). Camera Lucida: Reflections on Photography. New York: Hill and Wang.

Barthes, R. (2012). Mythologies: The Complete Edition, in a New Translation. New York: Hill and Wang.

Baudelaire, C. (1981). Selected Writings on Art and Artists. Cambridge: Cambridge University Press.

Benjamin, W. (1968). Illuminations. New York: Harcourt Brace Jovanovich.

Berger, J. (1972). Ways of Seeing. London: Penguin.

Berger, J. (2013). Understanding a Photograph. London: Penguin

Bergson, H. (1911). Laughter: An Essay on the Meaning of the Comic. London: Palgrave Macmillan.

Berlant, L. \& Ngai, S. (2017). 'Comedy has issues'. Critical Inquiry 43, pp. 233-249.

Booth, W. C. (1975). A Rhetoric of Irony. Chicago: The University of Chicago Press.

Brown, J. (2008). Escritos Completos sobre Velázquez. Madrid: Centro Estudios Europa Hispánica.

Carroll, N. (1991). 'Notes on the sight gag', in Horton, A. (ed.), Comedy/Cinema/Theory. Berkeley: University of California Press.

Casero-Ripollés, A. (2020). 'Political influencers in the digital sphere'. Communication \& Society $33(2)$.

Davis, J. M. (2018). (ed.). Satire and Politics: The Interplay of Heritage and Practice. London: Palgrave Macmillan.

Debord, G. (1970). The Society of Spectacle. Detroit: Black \& Red.

Didi-Huberman, G. (2016). The Surviving Image. Phantoms of Time and Time of Phantoms: Aby Warburg's History of Art. Pennsylvania: Penn State University Press.

Foster Wallace, D. (1998). 'Laughing with Kafka'. Harper's Magazine, pp. 23-27.

Foucault, M. (1970). The Order of Things: An Archaeology of the Human Sciences. New York: Pantheon Books.

Frye, N. (1957). Anatomy of Criticism. New Jersey: Princeton University Press.

Garin, M. (2014). El gag visual. De Buster Keaton a Super Mario. Madrid: Cátedra.

Garin, M. \& Elduque, A. (2016). 'Quantitative meta-analysis of visual motifs throughout film history'. El Profesional de la Información 25 (6), pp. 883-892.

González, J. J, Rodríguez, R. \& Castromil, A. R. (2010). 'A case of polarized pluralism in a Mediterranean country. The media and politics in Spain'. Global Media Journal: Mediterranean Edition 5 (1/2), pp. 1-9.

Gunning, T. (1995). 'Crazy machines in the garden of forking paths: Mischief gags and the origins of American film comedy', in Jenkins, H. \& Brunovska, K. (eds.), Classical Hollywood Comedy. London: Routledge.

Harris, E. (2003). Velázquez. Madrid: Akal.

Higgie, R. (2017). 'Under the guise of humour and critique: The political co-option of popular contemporary satire', in Milner Davis, J. (ed.), Satire and Politics: The Interplay of Heritage and Practice. London: Palgrave Macmillan.

Hofmann, W. (2003). Goya: To Every Story There Belongs Another. London: Thames \& Hudson.

Holm, N. (2017). Humour as Politics: The Political Aesthetics of Contemporary Comedy. London: Palgrave Macmillan.

Hutcheon, L. (2000). A Theory of Parody: The Teaching of Twentieth-Century Art Forms. Chicago: University of Illinois Press. 
Jenkins, H., Ford, S. \& Green, J. (2013). Spreadable Media: Creating Value and Meaning in a Networked Culture. New York: New York University Press.

Kaplan, L. (2017). Photography and Humour. London: Reaktion Books.

King, R. (2017). Hokum! The Early Sound Slapstick Short and Depression-Era Mass Culture. Berkeley: University of California Press.

Kress, G. R. \& van Leeuwen, T. (2006). Reading Images: The Grammar of Visual Design. London: Routledge.

Kress, G. R. \& van Leeuwen, T. (1998). 'Front pages: The critical analysis of newspaper layout', in Bell, A. \& Garrett, P. (eds.), Approaches to Media Discourse. New Jersey: Blackwell.

Mitchell, W. J. T. (2005). What do Pictures Want? The Lives and Loves of Images. Chicago: The University of Chicago Press.

Ngai, S. (2012). Our Aesthetic Categories: Zany, Cute, Interesting. Cambridge: Harvard University Press.

Ngai, S. (2017). 'Theory of the gimmick'. Critical Inquiry (4). Chicago: University of Chicago, pp. 466-505.

Ortega y Gasset, J. (1983). Papeles sobre Velázquez y Goya. Madrid: Alianza Editorial.

Panofsky, E. (1982). Meaning in the Visual Arts. Chicago: University of Chicago Press.

Pérez-Royo, J. (2020). 'Porque me da la gana'. ElDiario.es

Polo, D. \& Cárdenas M. L. (2014). 'Infoxicación y Tweets. Análisis del Caso Bárcenas a través del Twitter de Mariano Rajoy’. Ámbitos. Revista Internacional de Comunicación 26.

Ramírez, P. J. (2014). 'El estafermo. Carta de un Arponero Ingenuo'. Medium.

Rancière, J. (2004). Malaise dans l'esthétique. Paris: Galilée.

Rolfe, M. (2017). 'The populist elements of Australian political satire and the debt to the Americans and the Augustans', in Milner Davis, J. (ed.), Satire and Politics: The Interplay of Heritage and Practice. London: Palgrave Macmillan.

Sloterdijk, P. (1988). Critique of Cynical Reason. Chicago: University of Minnesota Press.

Sola-Morales, S. \& Hernández-Santaolalla, V. (2013). 'Identity, politics and authentic leadership. Spanish youngsters' perceptions of J. L. Rodríguez Zapatero and M. Rajoy'. Estudos en Comunicação 13, pp. 107-134.

Sontag, S. (1977). On Photography. London: Penguin. 